\title{
7 Inclusion at Provincial, Regional and District Level
}

UNESCO has provided useful guidance to support the development of inclusive education at regional and local level (Box 7.1). Its Open File on Inclusive Education is a compilation of strategies, which gives many examples of good practice from around the world. Starting with strategies for change, it describes how to initiate change, create new administrative structures and mobilise resources. It also provides support material for managers and administrators.

\section{Box 7.1 UNESCO Open File on Inclusive Education}

Professional development necessary for inclusive education

- A whole system approach which is part of general school improvement

- Supported school development where all the staff train together

- Where resources are scarce, Cascade models - but these are not as effective

- Distance learning using IT or post, where distances are great

- Reviewing the structures of teacher education so that all teachers receive training in inclusion

- Initial training ensuring that inclusive approaches are adopted throughout the system

- New roles for special educators that break down the divide between them and mainstream teachers

- Training the trainers - giving time and space for the reorientation of teacher trainers

- Making training systematic, so that it continues.

Quality assessment

- The aim of assessment is to make it possible for teachers and schools to provide responses to a wide range of diverse students.

- Assessment must help teachers plan for student diversity in their classrooms and help schools develop so that they become more inclusive.

- Much of the most useful assessment can be carried out by teachers themselves, and the range of techniques at their disposal needs to be extended by training.

- Where specialist assessment is undertaken, it must inform educational decisions about how students should be taught. This is more likely to happen if teachers have access to specialists who are in the school or work in teams close to the school.

- Parents, families and students can make an important contribution to the assessment process. 
- Early assessment of emerging difficulties is essential so that early intervention can take place. Early assessment is not just about the first years of the child's life: it is about identifying potential problems at any stage.

Organising support in inclusive systems

- Support includes everything that enables learners to learn, especially the resources that supplement what the ordinary class teacher can provide.

- The most important form of support is that provided from the resources at the disposal of every school - children supporting children, teachers supporting teachers, parents as partners in the education of their children and communities as supporters of schools.

- In many situations there will also be support from teachers with specialist knowledge, resource centres and professionals from other sectors. Where these forms of support exist, it is important to ensure that they contribute effectively to an inclusive approach. This may mean reorienting them towards providing support in mainstream schools in local support teams.

- Support must be delivered holistically: services and agencies must work together rather than in isolation from each other. This may mean creating local management structures for services which are the same as those for managing schools.

Participation of families and communities

- The participation of families and local communities is fundamental in assuring a quality education for all. Education is not simply a matter for professionals. Parents have often been the initiators of campaigns for inclusive education.

- Families and communities have a right to be involved and can make a range of contributions. In particular, they have knowledge of their children which professionals do not have.

- Building family and community involvement is a step-by-step process based on trust; special efforts are needed to promote the involvement of marginalised groups.

- Families and community groups can sometimes take a lead role as activists for inclusive education.

- Families' rights to involvement can be built into legislation or into the system of school governance.

- Communities can also be involved successfully in the governance of schools or of the education system as a whole.

- Schools can act as a resource for the community by offering services or becoming a base for other agencies.

Developing an inclusive curriculum

- The curriculum must be structured and taught in such a way that all students can access it. 
- It should be underpinned by a model of learning which is itself inclusive; it needs to accommodate a range of learning styles and to emphasise skills and knowledge that are relevant to students.

- It should have sufficient flexibility to respond to the needs of particular students, communities, and religious, linguistic, ethnic and other groups.

- It should have basic levels which students with varying levels of entry skills can access. Progress needs to be managed and assessed so that all students experience success.

- A more inclusive curriculum will make greater demands on teachers and they will need support in implementing it effectively.

Managing finance to support inclusive systems

- All countries face difficulties in finding adequate funds for education. It is important, therefore, to find ways of meeting students' needs that do not always call for extra funds and resources.

- It is important to establish partnerships between governments and other potential providers of funding.

- The separation of special and mainstream funding needs to be overcome and alternative methods for distributing funding should be developed.

- It may be necessary to fund programmes for overcoming disadvantage and equalising opportunities.

- Funders must be aware of the strategic behaviour that schools and others display, and use it for more inclusive purposes.

- It may be necessary to set up monitoring systems to ensure that funding and other resources are used appropriately and effectively.

- Even though levels of funding differ from country to country, many of the challenges and many of the strategies are similar.

\section{Involving disabled children and young people}

The Open File seems comprehensive, but it omits the role that should be played by disabled children and young people themselves. A recent UNICEF publication makes this point well (UNICEF, 2007). It stresses that there are numerous reasons why children's participation should be encouraged, in daily life as well as in policy development. These arguments are particularly strong in the case of disabled children:

- In advancing inclusion and overcoming obstacles, persons with disabilities themselves are the experts - nobody understands the impact of exclusion better than those who experience it;

- A key element of citizenship is the right to express one's views and to influence decision-making processes. Denying children with disabilities the right to be heard means denying them full citizenship;

- Decisions made about or on behalf of a child are better informed and more likely to produce positive outcomes if she or he is involved in the process; 
- The process of participation is a central part of learning to take responsibility and make decisions, and developing self-esteem and confidence;

- Children with no voice are vulnerable to abuse, violence and exploitation, since they have no means of challenging this oppression.

Putting such initiatives into place is not a highly specialised operation that requires significant additional resources. In practice, the inclusion of disabled children can be significantly advanced by simply consulting with these children and their families when setting up projects or structures intended for the general population or by maintaining an awareness of potential barriers to inclusion in new initiatives. Underestimation of the potential of children with severe impairments is perhaps the greatest obstacle, although experience has shown that all children can be helped to find the means to express meaningful choices and preferences. The Mpika project in Zambia (Box 7.27) demonstrates the importance of local leaders and the need to involve children through a child-to-child approach.

Some of the key tools for inclusion have been developed to support the empowerment of disabled children and adults. A number of these were developed by Marsha Forest and her colleagues in early pioneering work at the Centre for Integrated Education and Community in Toronto, Canada, established in 1989. More than two decades of inclusive education practice in Canada have significantly impacted on countries of the North. Marsha Forest is one of the recognised pioneers of inclusive education in North America. She began her career as a special consultant at the Montreal Oral School for the Deaf in 1968. After years of struggling to make inclusive education a reality in Canadian schools, she orchestrated a confrontation with school officials who had refused to admit students with mental 'handicaps' to Ontario schools. Several of these eventually became models of inclusive education. As demonstration schools, they have hosted visitors from all over North America and Europe. At the centre of this vision was Marsha's belief in children and their capacities.

This belief is manifested in several widely adopted best practices that began in Ontario schools: person-centred planning, making action plans (MAPS), circles of friends and PATH (planning alternative tomorrows with hope). These are powerful tools for building connections between schools, parents and communities, and for solving complex issues that may act as barriers to inclusive education. Evidence of the impact of this pioneering work abounds in the literature.

The Toronto Centre continues to initiate and support path-breaking activities to advance inclusion in education and communities. Examples include schools in the UK (Box 7.14) and applying a child-friendly approach in Vanuatu (Box 7.15).

\section{Inclusion at district level}

When inclusive education at regional and district level is examined, it becomes apparent that practice is very uneven, with the great majority of regions and districts still not moving beyond an integration model, where there is no change in the system.

In Canada and Australia, decisions on education policy are determined at the level of provincial government. In Canada there is a very mixed picture with, for example, New Brunswick (Box 7.2) and the Northwest Territories being fully inclusive in their provision, and a 'mixed economy' of inclusion and special schools in other provinces. In Ontario there are some pioneering school boards. A similar situation exists in Australia, where Queensland (Box 7.3), Tasmania and Victoria have strong policies on developing inclusive education. The national government has now agreed an equalities framework, under which all provinces will move towards inclusion 
The story of change in Hamilton-Wentworth Catholic District School Board in Ontario, Canada (Box 7.4) is an early example of systemic restructuring for inclusion led by a values-based approach; it was the first school board in the world to purposefully go for full inclusion. A similar approach was taken by a group of parents in the London Borough of Newham (Box 7.7) with remarkable success. The borough effectively removed the special school option by enhancing provision in mainstream schools and closing its special schools. New Brunswick stands out as a similar beacon. The early years education project in Dharavi, Mumbai (Box 7.8) proves that developing inclusive practice at a local level is not just about resources, but about changing attitudes and developing good practice; the project has successfully transitioned to schools. Experience in Alberta, Canada demonstrates that the inclusion of disabled students with learning difficulties can be successful in post-school education (Box 7.6). Box 7.5 shows how whiteboard technology was adopted as a tool for inclusion by a Canadian school board.

Boxes 7.10 and 7.11 demonstrate how Leonard Cheshire Disability has developed models of inclusive education by enlisting the community, training teachers linked with a university and using child-to-child methods in districts of Kenya and Uganda. Projects in Malawi (Box 7.12) and Zambia (Box 7.13) are also important African exemplars. The 'Inclusive Tanzania' programme in Mwanga District and Dar-es-Salaam (Box 7.25 ) is another innovative project that has mobilised the whole community behind inclusive education. Teacher training and attitudes are important: Boxes 7.22 and 7.23 demonstrate different aspects of this. Links with parents and community are particularly vital: this is demonstrated in Kerala (Box 7.20) and Quebec (Box 7.17).

The need to include other children to create collaborative working is emphasised in Mpika, Zambia (Box 7.13), Vanuatu (Box 7.15) and the UK (Box 7.14). Experience in Bushenyi, Uganda demonstrates how deaf education can work in Africa (Box 7.26).

\section{Box 7.2 New Brunswick, Canada: Inclusive education as official policy}

Inclusive education became official policy in New Brunswick in 1968 and this was confirmed in the 1985 amendment to the Schools Act. Every school in the province is required to provide inclusive education. Virtually all students are educated in ordinary classrooms, with specialist support as needed, based on the student's individual education plan. Key features of best practice in New Brunswick schools include:

- The belief that all children can learn if they are given appropriate learning support

- Planning individualised learning

- Developing support teams

- Promoting social skills and responsibilities among the children

- Assessing children's performance

- Planning for transition from one stage to the next

- Working in partnership with parents and other members of the community

- Implementing staff development plans

- Being accountable 
The inclusion programme has enhanced the learning of both disabled and nondisabled pupils. An OECD report shows that a New Brunswick district ranked highest in standardised English and Maths examinations in Canada in the years it covered, and had one of the highest graduation rates in the country.

The province allocates block funding to school districts based on the numbers of students enrolled. If C $\$ 350$ is available per student for special needs education programmes, a district with 30 schools and 10,000 students receives $\mathrm{C} \$ 3,500,000$. Districts can use this funding as they see fit. They might, for instance, allocate 75 per cent to provide support teachers and classroom assistants to schools on a per capita basis; a further 15 per cent might be used to provide more resources for schools with greater needs; 10 per cent might be held in reserve as a contingency. This system of devolution is sufficiently flexible to respond to differing levels of need, but does not require costly referral procedures. It therefore frees resources such as educational psychologists' time, so that they are available to support inclusive provision.

While New Brunswick is a small, rural and diverse province and faces economic challenges, it has provided a positive model of inclusive education in Canada, and indeed for other countries, for more than 20 years. Its success has been recognised by the OECD and UNESCO.

Inclusive education has been mandated by provincial legislation since 1986. In the early 1980s special classes, special schools and a children's institution remained as key parts of a system that failed to assure equity or service to many children. One impetus for change was the Canadian Charter of Rights and Freedoms, adopted in 1982 and effective in 1985. In addition, there was significant demand from parent groups and educators for more integrated and inclusive school programmes. As a consequence, in 1986 the legislative assembly unanimously passed Bill 85 . It addressed the equality and procedural issues for educational practice that flow from the Charter. The closure of the WF Roberts Hospital School, a children's institution, and the dismantling of the auxiliary school system followed. The result was strong legislative and policy support for inclusive education in one of Canada's smallest provinces.

The province had gradually accepted more responsibility for educating disabled students in the decades leading up to 1986 and several school districts adopted inclusion as their policy before the legislative changes. These districts, specifically what is now District 14, based in Woodstock, started to develop approaches and practices that made the vision of inclusion a reality.

Supports were developed for teachers and students; training was focused on school and classroom practices; support teachers were trained to assist with programme planning and implementation. School-based support teams were brought together and school leaders were trained in the essentials of providing leadership in an inclusive school. Strategies were developed that emphasised multi-level instruction and curriculum adaptation. School-based problem solving was made a feature of school culture. The approach withstood a major and very political review in 1989, another in the mid-1990s and a thorough examination, published as the MacKay Report, in 2006 (New Brunswick Department of Education, 2006).

The MacKay Report drew on a wide-ranging consultation with teachers, parents, community and disabled groups and the Aborigine population. It found 


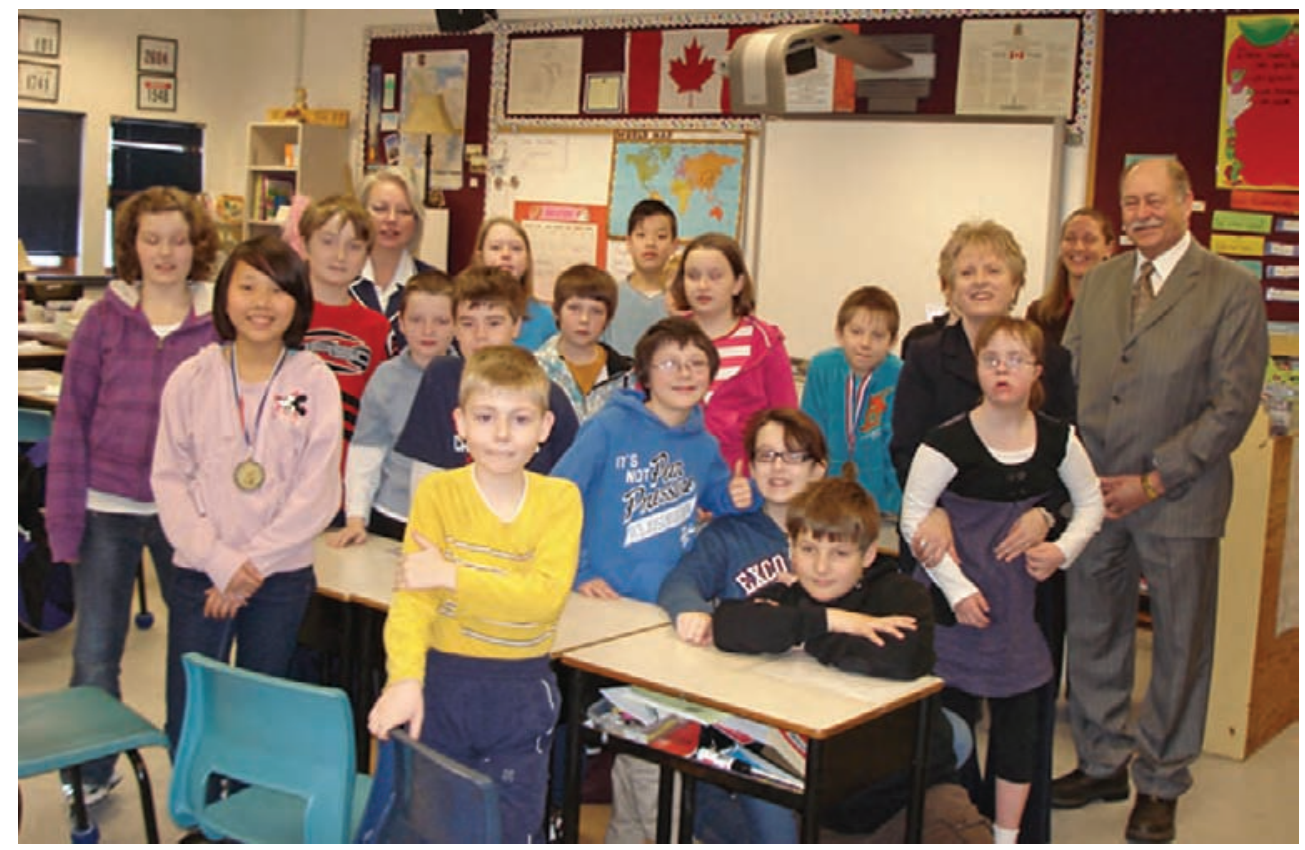

A provincial government minister visits Connaught Street Inclusive School in New Brunswick. CREDIT: NeW BRunswick Provincial Government

widespread support for a child-centred, inclusive approach, but pointed out: 232

The status quo is not an option. New Brunswick has been a leader in the concept and philosophy of inclusion, but must move to the next stage of becoming a leader and innovator in implementation and service delivery. Enhancing the inclusive education system could draw immigrants into the province. 'Would-be' immigrants to New Brunswick would be attracted to a system that truly takes account of differences in an effective and positive way.

Guidelines issued by the province's Human Rights Commission state:233

Full participation in regular school programmes with non-disabled peers is the goal set explicitly in the Education Act (New Brunswick) and the Convention on the Rights of Persons with Disabilities as well as by the case law under the Canadian Charter of Rights and Freedom (1982) and the Human Rights Code. Education providers and teachers must be provided with support sufficient to assure that students with a disability can achieve educational goals and do so side by side with their peers in community schools. ... The more or less routine placement of students with disability into special or separate classes for students with disabilities may be considered to be discriminatory as it represents a failure to accommodate, since the individual requirements of each student are not considered.

The guidelines explain the 'duty to accommodate', as well as the criteria for 'reasonable accommodation', and the limitations on the duty to accommodate. They also emphasise the importance of taking reasonable steps to accommodate parents with a disability to ensure that they have the opportunity to communicate effectively with the school and are able to actively participate in their children's education. The guidelines apply to most kindergartens and to schools up to Grade 12; there are some exceptions, such as First Nations schools, which fall under federal law.

\section{What does 'accommodation' mean?}

Accommodation means removing barriers and taking steps to engage students in a way that helps them reach their potential both academically and socially. 
A student with a physical impairment may need accessible facilities, special equipment or technologies. A student with a mental impairment may need alternative teaching methods, adjustments to the curriculum, one-on-one assistance from a teaching aide or some time in a specialised group setting. Solutions must involve respect for the student's dignity.

The guidelines emphasise the importance of supporting students with disabilities so they can be included in regular classes, as well as ensuring they have access to extra-curricular activities. Reasonable accommodation will be different for each student or parent and it is important to meet the individual's specific needs. Special needs and abilities, which may develop or decline over time, require that accommodations and strategies be assessed early and reassessed frequently.

Are there limits on the duty to accommodate?

Accommodations must be 'reasonable'. The objective is to provide the student with the means to meet their individual potential. What is reasonable will vary from case to case and must consider factors such as:

- The needs of the individual

- The cost of the accommodation

- The risk to health and safety

- The impact on other people and programmes

What do the guidelines say about discipline for students with a disability? In some cases school discipline policies, especially zero tolerance policies, may be unfair for disabled students. If the impairment is a factor in the student's discipline problem, steps must be taken to develop a strategy for dealing effectively with the disruptive behaviour. If the behaviour poses a health or safety risk to the student, to other students and/or to teachers and other staff, it may be necessary to make specific and individual arrangements for the student's education.

Responsibilities of education providers, students and parents

The guidelines state that education providers have a responsibility to:

- Anticipate and plan for accessibility and inclusion;

- Ensure staff have the training they need to accommodate disabled students;

- Assist with assessment and education planning with the help of experts or specialists as needed;

- Deal with accommodation requests in a timely manner.

- Provide for the right of all students, including students with a physical or mental impairment, to reach their individual potential;

- Ensure that schools are welcoming and that all students treat one another with respect;

- Take immediate action in situations where bullying and harassment may be taking place. 
Unions, professional associations and others involved in providing education and support services are also part of the accommodation process and have a responsibility to support accommodation measures. The student and their parents or guardians have the right to expect reasonable steps to be taken to accommodate their needs; however, they also have a role to play. The responsibilities of parents and students include:

- A duty to work with the schools;

- Keeping education providers informed by providing information about the need for accommodation. This may involve providing information from health care professionals about restrictions or limitations.

In the case of harassment and bullying in public schools, the Department of Education provides a separate complaints process. A complaint can also be filed with the Human Rights Commission.

\section{Box 7.3 Queensland, Australia: Inclusion through school improvement}

In 2002 the Queensland Government established a taskforce on inclusive education whose remit was to look at inclusive education for disabled students. ${ }^{234}$ It had already developed a review of its schools through Queensland 2010, the Queensland School Reform Longitudinal Study ${ }^{235}$ and other approaches that focused on the quality of teaching and learning needed to enable young people to continue learning throughout their lives. Part of the review was a working party leading to a summit of stakeholders. The aim of the summit was to engage stakeholders in the development of a vision of inclusive education for all students in the context of Queensland 2010.

Its objectives were to:

- Develop a common understanding of the notion of inclusive education;

- Challenge current thinking and assumptions on school structure, curriculum and practices;

- Learn from the experiences of other countries, states and schools that are pursuing an inclusive framework;

- Provide an overview of current Education Queensland practices, policies and cultures, and their relationship to an inclusive framework;

- Develop a communication process to progress the identified actions;

- Identify and underline the articulations between disabled students and other disadvantaged and marginalised groups.

The working party was concerned that there should be input into the process from members of the schools community across the state. Queensland is a large state, divided into 36 education districts. The working party decided to conduct a focus group in each district in the ten weeks leading up to the summit. The purpose of the groups was fourfold:

- To ask participants what issues they were concerned about in implementing an inclusive education framework in their school, district or classroom; 


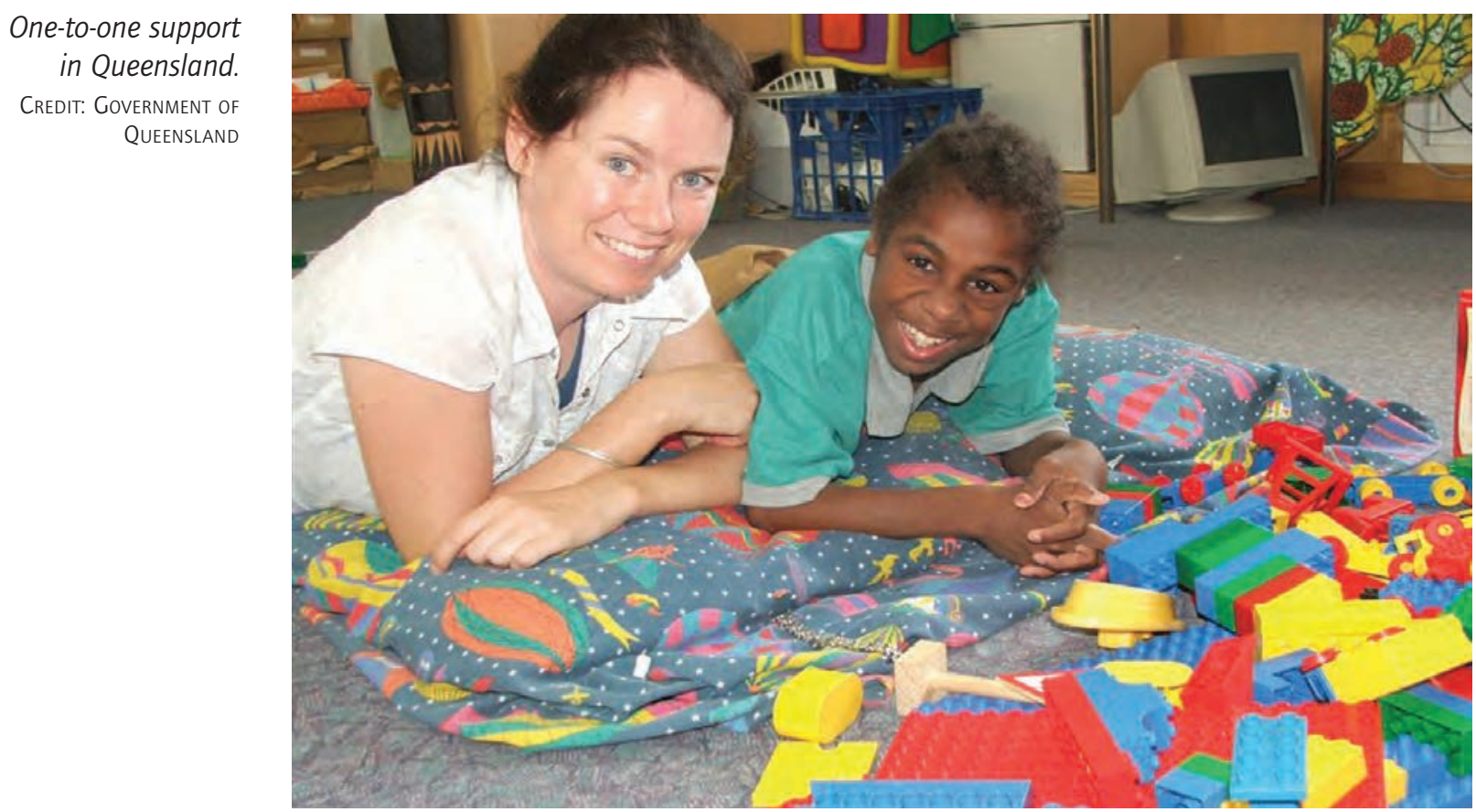

- To identify examples of innovative practice that promote inclusive education;

- To give participants the opportunity to explore some issues in depth in setting future directions in the district, school or classroom;

- To elect a representative from the group to attend the summit.

The top issues featured in the consultation were: teacher training; attitudes and values; provision of resources and funds; the development of a shared understanding about inclusive education; the inclusion of other categories of need in the funding equation; curriculum practices; developing relationships between the school, parents and the community; student-teacher ratios; buildings, classrooms and access. ${ }^{236}$

Ninety-four delegates were invited to the summit, held 29-31 May 2002. Delegates represented all sectors of Education Queensland and other government departments, the non-governmental sector and parents. Students with experience of exclusion from school talked to a group of participants. Representatives of ten schools that had begun to develop inclusive education also visited the summit. These two activities had a great impact on the delegates and helped in the development of a common understanding.

Delegates were asked to identify actions across the education system, and at district, school and community levels and the meeting culminated in the development of an action plan.

The summit defined inclusive education as: 'a process of responding to the uniqueness of individuals, increasing their presence, access, participation and achievement in a learning society'. The principles underpinning inclusive education were identified as responsiveness to the uniqueness of individuals; the importance of partnerships; equitable opportunities for students to maximise their learning potential; a learning community that questions disadvantage and challenges social injustice; and accountability of individuals and organisations in contributing to inclusive education. 


\section{Recommendations}

1. That the Queensland Government publicly support the vision of an inclusive society.

2. That the Minister promote a vision of inclusive education for diverse learners and lead the implementation of comprehensive system changes.

3. That the Minister prepare and promulgate a Green Paper on inclusive education.

4. That the Minister take steps to ensure that the importance of communities, and particularly families, is translated into effective policy and practice.

5. That schools implement policies to embed collaborative relationships with parents and carers, and, where possible, children.

6. That schools provide accessible information about their dispute resolution processes and that an independent complaints mechanism be developed.

7. That the Queensland Studies Authority develop syllabuses and other documents that support the development of an inclusive curriculum by December 2006.

8. That the Minister establish a rigorous research programme in all schooling sectors of Queensland along the lines of the Queensland School Reform Longitudinal Study.

9. That ascertainment, as a process for the allocation of resources, be phased out by 2005 and that a new resource allocation methodology be developed.

10. That professional development programmes focusing on strategic implementation of the vision be developed and implemented within a planned timeframe.

11. That by January 2006, all Queensland pre-service teacher education programmes be required to ensure that inclusive education is a pervasive theme in their courses.

12. That the teacher application process include reference to inclusive education theory and practice.

The targets appear to be being met - staff training is well established and the resourcing model educational adjustment programme is in place. This is then verified by the government against medical assessments of impairment in six categories $^{237}$ and extra resources are allocated to schools through local districts. ${ }^{238}$

A taskforce on the inclusion of students with disabilities carried out further work in 2003-2004. ${ }^{239}$ It developed a vision for inclusive education:

Quality education is made available to, and accessed by, all Queenslanders, underpinned by respectful relationships between learners, teachers and parents/caregivers. It is supported by collaborative relationships with communities and governments. It excludes no one, welcomes all. Growth in wisdom and humanity is celebrated.

The taskforce endorsed the recommendations made by the 2002 summit. 


\section{Conclusion}

The new vision of inclusive education underpins the smart state. Inclusive education contributes to building community capacity to value all its members. Teachers, parents and caregivers and other community members work together to create and implement socially just visions of what they wish to achieve.

Universities have an opportunity to prepare teachers for inclusive schools and engage in regional and local issues in ways that transform the preparation and continuing development of teachers. The single greatest challenge as we move forward is the education and re-education of teachers, parents and caregivers and the community about the theory and practice of inclusive education.

In 2010 a booklet for parents of children with disabilities was issued. This gives an up to date summary of the Queensland approach.

The Department of Education and Training (DET) is committed to ensure that all students, including students with disabilities can access, participate and succeed in education on the same basis as other students.

International research has provided evidence that whole-school based intervention models are effective in improving the educational performance of all students, especially for those students with social, communication, emotional and behavioural difficulties.

DET provides a variety of supports and services to all students, including those with disabilities ... School communities create and sustain supportive environments where all students feel a sense of belonging. Inclusive school communities support diversity and have a whole-school approach to planning for learning, teaching and assessment which meets the needs of all students. It is recognised that some students will require additional targeted educational support to meet their needs. These students are supported through the full array of student support services allocated to regions and schools and this may include assistive technology, alternative format material, special provisions for assessment, speech-language therapy services and learning support. Students who have specialised educational support needs may be eligible for additional targeted resources if they are identified as meeting criteria for one of six Education Adjustment Program (EAP) disability categories of Autism Spectrum Disorder, Hearing Impairment, Intellectual Impairment, Physical Impairment, Speech-Language Impairment and Vision Impairment.

The principal is responsible for ensuring that all students are provided with the appropriate educational adjustments to enable them to access the curriculum. Collaboration with parents and carers is an important part of the process of identifying and responding to the individual needs of students.

Students with disabilities are entitled to enrol at any state school in Queensland under the same conditions as students without disabilities. The majority of students with disabilities attend the same education facilities as their peers. There is a wide variety of support to meet disabled children's needs.

There are special schools but only those with intellectual impairment may attend. 240 


\section{Box 7.4 Hamilton-Wentworth Catholic District School Board, Ontario, Canada: Each belongs}

The move to inclusion by Hamilton-Wentworth Catholic District School Board (HWCDSB) started in 1969, led by Jim Hansen, the Board's Deputy Principal, who was in charge of special education. Today, the Board's schools cater for 30,000 students and it does not have a single special class or special school. Every student with special needs attends lessons in a regular classroom in a community school alongside their peers. Regular classroom teachers, supported by administrators and special education teachers, welcome and teach all students. How did this change come about?

In the 1950s and 1960s Canada was growing fast, with good jobs and an expanding immigrant population. School boards were reorganised at a time of change in educational philosophy so that they took a less regimented and more child-centred approach. Many teachers were recruited to the expanding school boards from the UK, USA and Caribbean. In 1968, a review of special education by a representative committee of teachers, principals and administrators was set up with the aim of moving away from a parallel special school system and methods. The review involved a wide literature survey, interviews with practitioners and an audit of current practice. This identified that out of 23,000 children, 21 per cent had special educational needs. The review group found that these were not being met and in 1969 it made 21 recommendations, 12 of which were priorities.

Normative and intelligence tests were abolished and replaced by a child-focused approach. A teamwork model was introduced, giving rise to a genuinely creative innovation - the diagnostic prescriptive team with new special needs resource teachers in every school. The team was school based and mandated to meet weekly and respond to the needs and requests of students. In doing this, it received backing from support services and comprehensive support systems were set up. Staff were proactively supported by relevant in-service training. The review group continued as the driving force of the new initiative and was copied by many other school boards in Canada and beyond.

The change in values that was brought about in the HWCDSB, leading to demonstrably effective inclusive practices in its schools, is underpinned by the Each Belongs Credo:

- Each person is endowed with the dignity of a person.

- Each person has equal value despite differences in ability.

- Each person has a right to grow and indeed each person can grow.

- The limits of individual growth are unknown and should not be circumscribed.

- No person is static, each is ever in the process of becoming.

- Each person is unique and unrepeatable.

- The beliefs we hold about people can serve as prison walls limiting us at every turn. 
- They can also set us free from our shackles to confront great new possibilities never dreamed of before.

- Life is the ultimate gift and learning is its crowning.

When we look back on nearly 40 years of the development of inclusive education, what has been learned?

1. There is not any one ideal setting or one right way to do it.

2. No child can fail at inclusion.

3. There are no prerequisite skills or behaviours that are necessary before a child can be successfully included.

4. Teachers do not need special training to be successful in inclusive classrooms.

5. Inclusion is most likely to be seen as successful by those involved when a co-ordinated supportive team approach is used.

6. Teachers and children should not be afraid to make mistakes and learn from them.

7. Take things one day at a time. Don't try to solve all the problems today or even this week.

8. An individualised education plan with clear goals and rationales, with plenty of input from everyone, including parents, goes a long way towards making people feel: 'We're on the right track and progress is being made'.

9. This is a journey where all are learning, step by step, as they travel. It is important for everyone to be patient with themselves and with others.

10. Even if it feels as if everything is going wrong, keep at it, talk with others and ask for help - some days are like that. Remember, this is real life. ${ }^{241}$

\section{Box 7.5 Ontario, Canada: From vision into practice ${ }^{242}$}

'Inclusion is not a strategy to help people fit into the systems and structures which exist in our societies; it is about transforming those systems and structures to make it better for everyone' - Diane Richler, President, Inclusion International.

In 2008-2009 a multi-disciplinary team of educators, speech-language pathologists and technologists developed Smart Inclusion, an idea that originated as a method to support inclusion and programming for students with significant barriers to communication. The initiative examined the use of interactive whiteboards with what has historically been thought of as 'special needs software and hardware', set within a framework that includes universal design for learning (UDL), ${ }^{243}$ differentiated instruction (DI) ${ }^{244}$ and the participation model (PM). ${ }^{245,246}$

In May 2008, 12 children with significant communication challenges were identified as eligible for a grant to purchase specialised equipment and software. This included augmentative and alternative communication (AAC) tools, an 
interactive whiteboard and application software considered essential to augment and assist not only communication but meaningful educational and social participation in the classroom setting for the student with severe disabilities. ${ }^{247}$ A model of support was developed for goal setting and programming, training and

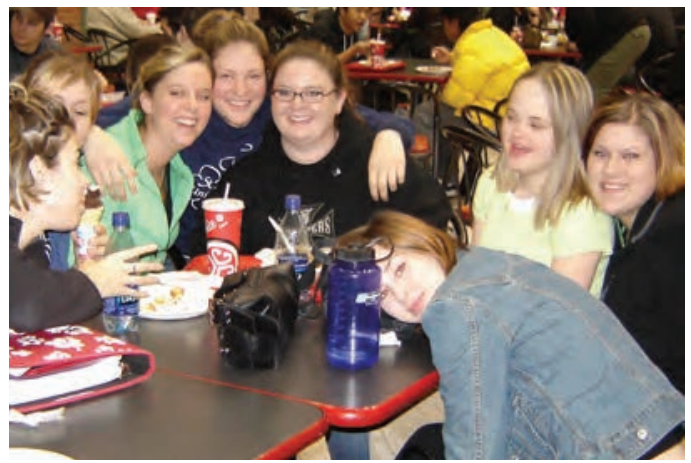

Friends at college. CREDIt: AACL coaching, and framed as the 'Smart Inclusion' approach. This approach is student centred, goal focused and process oriented. A team of people including educators, professional services staff, technologists, parents and students begins by identifying barriers that are preventing a student from participating in classroom learning activities and settings. From there, instructional methods and tools are identified that will remove or circumvent the barriers, thus enabling and optimising student participation. Throughout, support and professional development are provided that build learning communities with a focus on inclusive education.

Throughout the 2008-2009 school year, the academic and social participation, communication and learning skills, and behaviour of target students were tracked via assessment, observations, interviews and surveys conducted before and after the implementation of Smart Inclusion.

Compared to the year prior to Smart Inclusion, target students were spending more time in class and were engaged more often in learning activities with their peers. More communication opportunities and more successful communication attempts occurred for target students than in the previous school year, and they demonstrated more rapid growth in their speech and language skills. Attendance improved and negative behaviour decreased from one year to the next. In addition, teachers felt that all students were more engaged when assistive technology was used for whole class instruction. ${ }^{248}$ This approach can be used in small groups, pairs or individually with a touch screen laptop.

That some students have significant learning 'challenges' was never in question. However, it was felt that the 'challenges' lie with the educators - to design pedagogical practice, classrooms and school communities that reach and teach all students. Work with more students and schools continues, looking at the pairing of pedagogical practices with mainstream and assistive technology, and how professional development that includes the opportunity to learn with and from others contributes to inclusion. ${ }^{249}$ As Booth and Ainscow (2002) assert:

Participation in education involves going beyond access. It implies learning alongside others and collaborating with them in shared lessons. It involves active engagement with what is learned and taught, and having a say in how education is experienced. But participation also involves being recognised for oneself and being accepted for oneself. I participate with you when you recognise me as a person yourself, and accept me for who I am. 


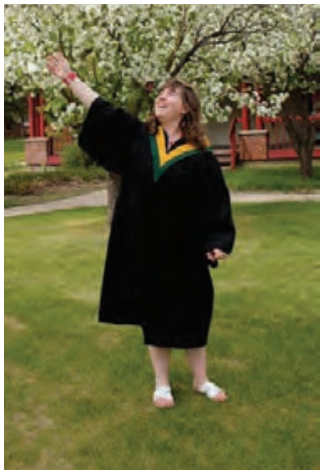

Graduating from college in Alberta. CREDIT: AACL

\section{Box 7.6 Alberta, Canada: Post-school inclusion}

A Promising Path to an Inclusive Life showcases the Alberta programme of inclusive post-secondary education for adults with developmental disabilities (Uditsky and Hughson, 2008). Many of the students failed to get an inclusive primary or secondary education, but students with learning difficulties attend regular classes in a wide variety of courses and faculties in universities, colleges and technical institutes. They make friends, belong to clubs and participate in informal and formal life of these tertiary establishments. Many of the students have graduated. Seventy per cent go on to careers, employment and a richer life in the community. The DVD Living the Dream provides an excellent overview of this project. ${ }^{250}$

The programme started 20 years ago and in 2008 more than 70 students were supported with a few extra staff in each college. When it is working well the programme is almost invisible. Non-disabled peers have also gained a great deal. Each student has an individualised course supported by peers and teachers. The view of the teachers is that the system has stimulated learning in class and broadened students' experiences. Plans are well advanced to take the programme into every post-secondary establishment in Alberta.

\section{Box 7.7 Newham, London: Inclusion in the inner city}

The London Borough of Newham shows how moves towards inclusion can be made in a poor multicultural inner city area. Located in the London's East End, Newham underwent a major transformation as the docks closed and new sources of employment moved in. In 1984, a group of parents of disabled children were elected to the borough council with the express wish of ending segregated special education. They achieved their aim when the council adopted policy recognising the right of all children to learn together. Since then, it has been committed to developing inclusive education. Over a ten-year period they closed special schools and put the resources into mainstream.

The original council policy document states:

The London Borough of Newham believes in the inherent equality of all individuals irrespective of physical or mental ability. It recognises, however, that individuals are not always treated as equals and that young people with disabilities experience discrimination and disadvantage. The Council believes that segregated special education is a major factor causing discrimination. We therefore believe that desegregating special education is the first step in tackling prejudice against people with disabilities and other difficulties. They have been omitted from previous equal opportunities initiatives, and it is now obvious that our aim of achieving comprehensive education in Newham will remain hindered while we continue to select approximately 2 per cent of school pupils for separate education. It is also the right of pupils without disabilities or other difficulties to experience a real environment in which they can learn that people are not all the same and that those who happen to have a disability should not be treated differently, any more than they would be if they were of a different ethnic 


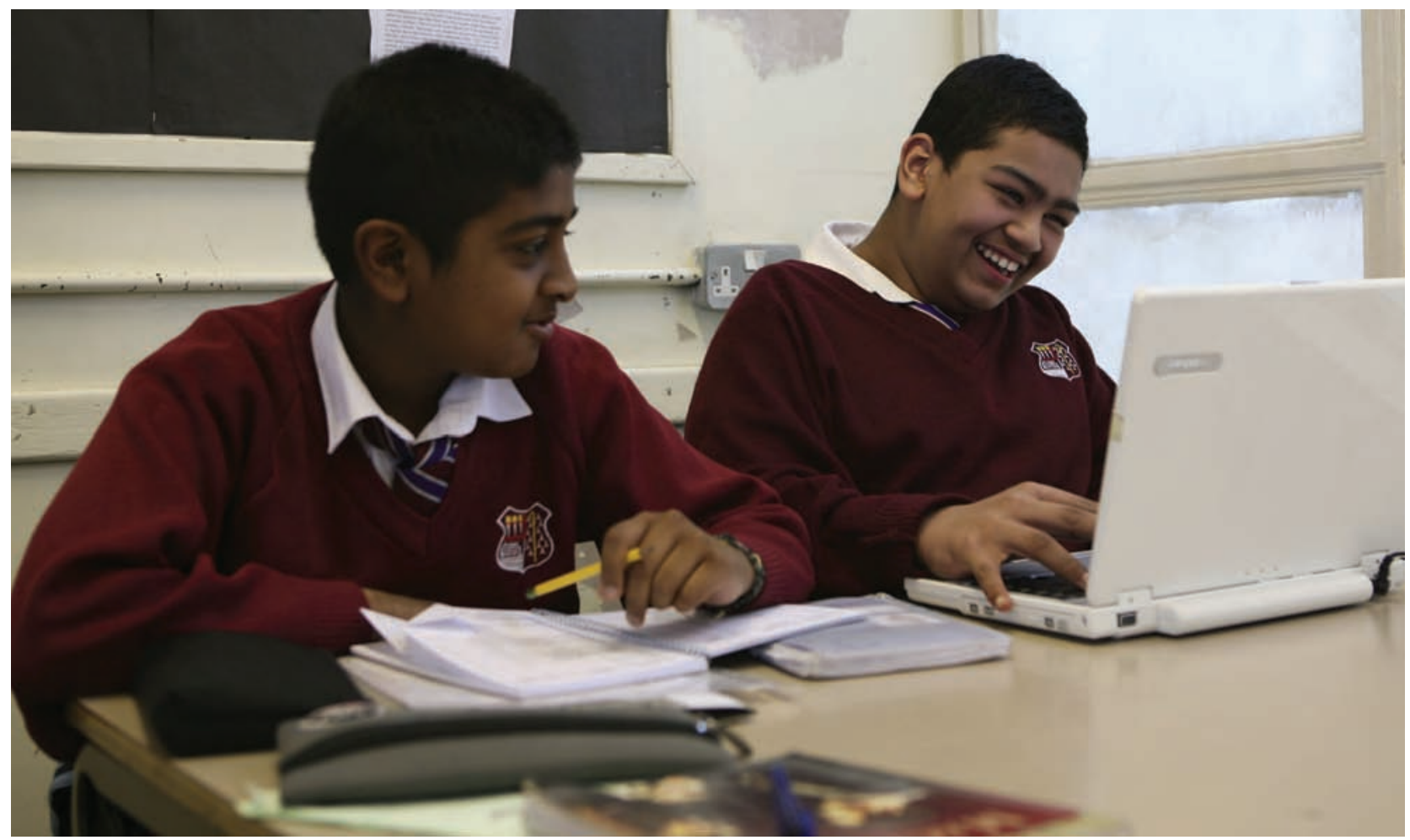

background. It is their right to learn at first-hand about experiences which they will possibly undergo in future, either themselves or as parents. Desegregating special education and thus meeting the needs of statemented children in mainstream schools will also contribute, by the entry of expert qualified staff into mainstream schools, to improved provision for the considerable number of children who already experience difficulties.

Methods used include:

- A signed agreement with trade unions to ringfence resources saved from special school closure to support mainstream inclusion, which is reviewed annually;

- An ongoing debate and training for teachers and other education professionals, school governors and parents;

- The development of an inclusive early years' service;

- Funding schools so they can support the needs of all children;

- Agreement that any money saved from school closures should be used to provide teams of specialist support teachers;

- Putting inclusion at the heart of all education policies;

- Creating resourced schools for different impairments as a transitional step;

- Ensuring that all new buildings are fully accessible;

- Providing ongoing political support and leadership.

The borough's policy has the goal of making it possible 'for every child, whatever special educational needs they may have, to attend their neighbourhood school'. From 1984 to 1994, the number of special schools in the borough fell from eight to one, and the number of children in special education dropped
Peer support in using a laptop.

CREDIT: WoRLd OF INCLUSION 
from 913 to 195. Parents became increasingly confident that their neighbourhood schools could meet diverse needs.

It has been argued that inclusion in Newham was achieved by exporting pupils with the most severe impairments to other boroughs. Newham has 17 resourced mainstream schools. In 2011, only 198 pupils were not in mainstream schools. Of 53,523 pupils, only 0.36 per cent were not in mainstream schools, compared to an average for England of 1.27 per cent. ${ }^{251}$ This was achieved in a hostile national educational and political climate. Resourced schools were set up to meet needs in mainstream schools in response to parental concerns. These were to be phased out as Newham moved to inclusive neighbourhood schools, but they have remained.

From the start, the process envisaged radical changes in mainstream schools, rather than fitting children with special educational needs into the existing system. The local education authority appointed four officers to address the process of developing inclusion from integration. An independent report commented that catering for children with serious learning difficulties helps schools make better provision for all pupils. This is borne out by results. In 1997-2000 Newham schools had the biggest improvement in their GCSE results for all pupils in the whole country. Many children labelled as having severe learning difficulties were now passing exams. In addition, the number of exclusions from school for bad behaviour fell. By 2011 this ongoing process had been hindered by reliance on league tables based on normative testing prescribed by the government. Despite this, some schools have remained strongly inclusive in their ethos and practice..$^{252}$

\section{Box 7.8 India: Early years education in Dharavi, Mumbai}

In 1974 the Indian Government began to introduce early childhood care through the Integrated Child Development Services (ICDS) scheme. This has expanded to reach more than 50 per cent of the vulnerable population, providing supplementary nutrition, immunisation, health check-ups and referrals, and preschool education for 3 to 6 year olds. Dharavi, Mumbai is the largest slum in Asia, with over 600,000 residents living in small $10 \times 10$-foot shacks, built out of whatever comes to hand and lacking basic sanitation. Research established

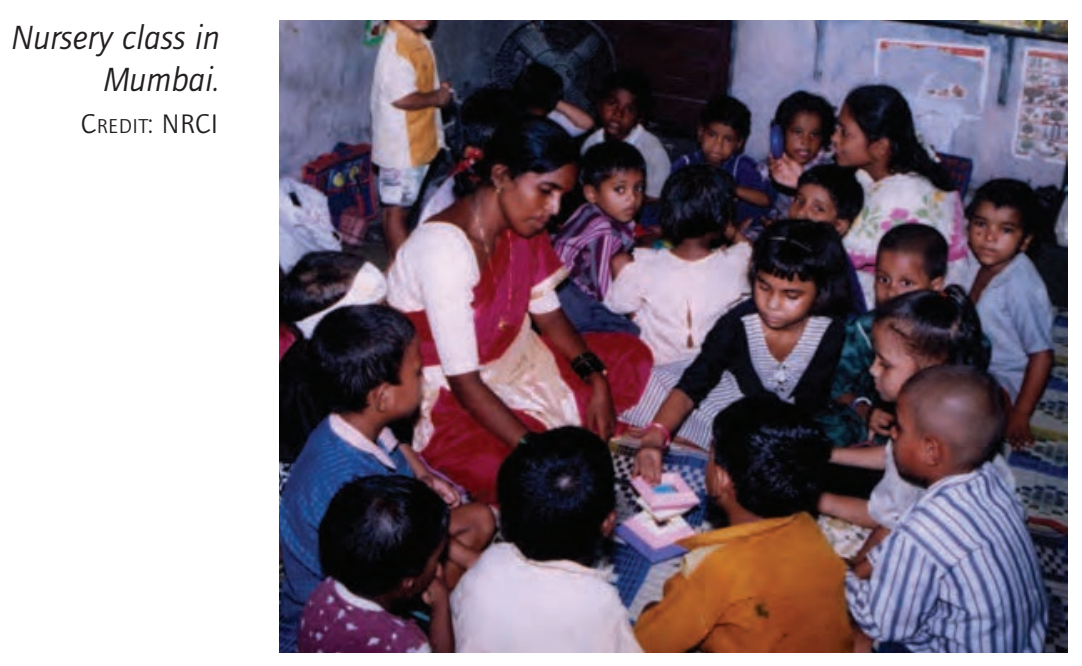
that disabled children were excluded from the ICDS and that parents and workers opposed their inclusion (Alur, 1998).

The National Resource Centre for Inclusion (NRCl), formerly the Spastics Society of India (SSI), developed a project with UNICEF that included disabled children in six anganwadis (nurseries) 


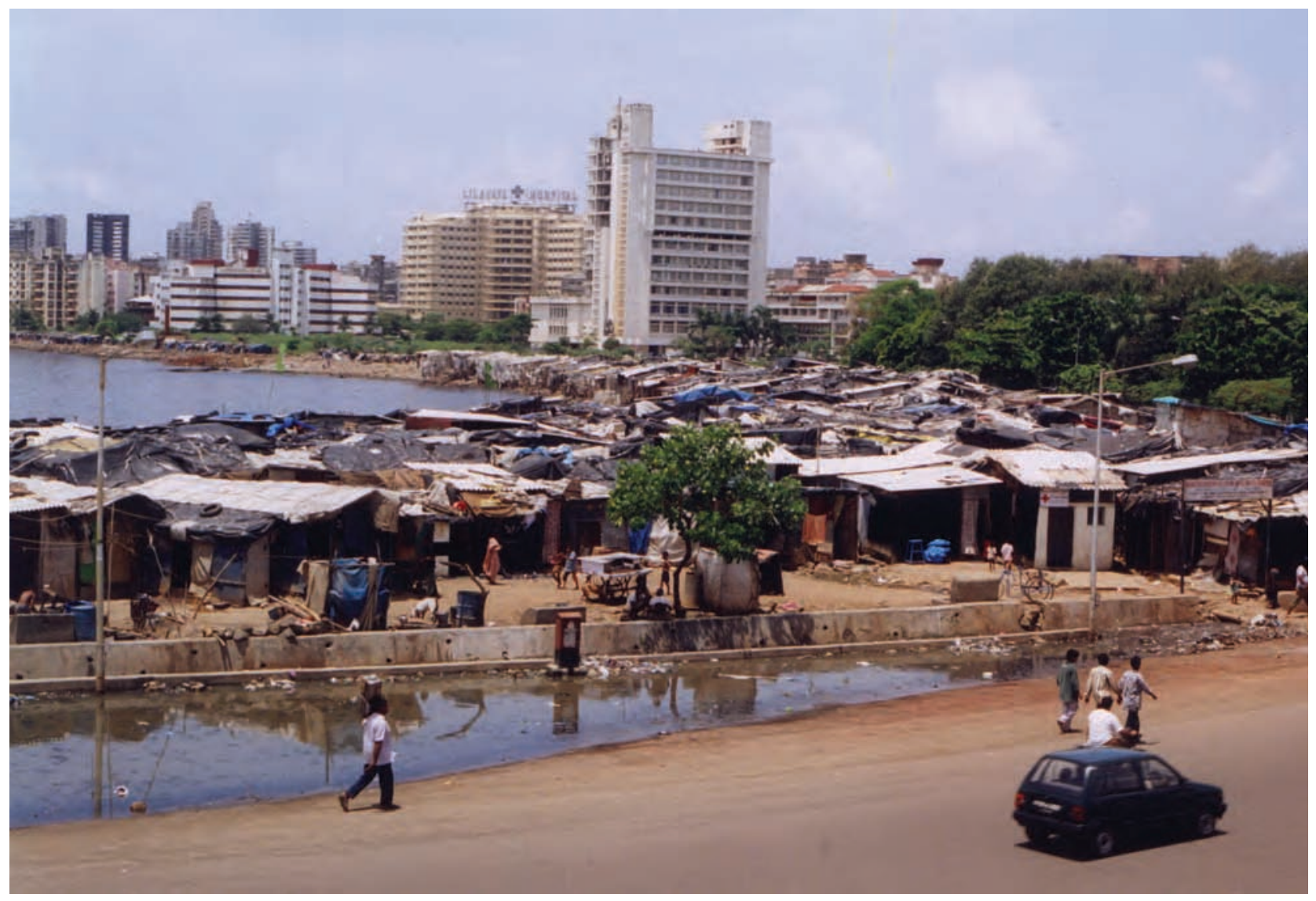

(Alur and Rioux, 2004). This was later funded by the Canadian Government and expanded to 16 . Three years after its inception, the programme provided pre-school education for more than 1,200 children, employing local women

Dharavi, Mumbai, India.

Credit: Carlos Reyes Manzo trained by the $\mathrm{NRCl}$ and materials found in Dharavi. Impoverished children from the slums, girls and disabled children receive daily instruction based on an accepted early childhood curriculum, including personal hygiene, nutrition and English. This has created a cost-effective model of inclusion in the community. Research has shown big positive shifts in attitudes towards disabled children by all concerned.

In the first six pilot anganwadis 432 children were enrolled, 43 of whom were disabled. A capacity training model was developed for training anganwadi multi-purpose workers (two per setting), community workers and helpers. This was followed up with enrichment, therapeutic and education training. Parent meetings took place at all settings, complemented by focus groups to ascertain changes in attitudes. Parent education sessions were held to disseminate information. The views of individual parents were ascertained through doorto-door visits. A micro longitudinal study was carried out to discover whether children's needs were being met and whether attitudes were changing.

New tools were needed. Barriers to inclusion included the attitudes of professionals and fear of disability. Developmental scales were used for tracking changes in six areas: the motor, emotional, social, communication, creativity and functional skills needed for independence. An ecological curriculum using resources from the community was adopted.

In the first six months of the pilot the disabled children showed a much greater range of developmental gain than the non-disabled children. There was also an 
overall decrease in barriers facing the disabled children. The key change in parents' attitudes was that they became more satisfied with the school. The project was also successful in addressing negative attitudes. In households with disabled children there was a positive shift in how they valued them. (See DVD 1)

\section{Box 7.9 Developing inclusive education in Mumbai schools}

Following on from the groundbreaking work in Dharavi described in Box 7.8, disabled and non-disabled students from the three Spastics Society of India centres in Bandra, Colaba and Dharavi were included in 76 schools across Mumbai. These are now partner schools and include both state-run and private schools. Hooja (2010) describes how the setting up of an Inclusive Education Coordination Committee (IECC) eased the process of inclusion. ${ }^{253}$

It was found that disabled students and young people do need additional resource support until the environment (including teachers, parents and the community at large) is sensitised and made conducive to inclusion. Experience showed that to sustain this inclusion, it was critical that the children, parents and schools received ongoing support. Enabling students to make a successful transition from a special school to an ordinary school was a difficult task. Parents, schools and students required frequent counselling and attention needed to be paid to seemingly insignificant issues.

\section{Inclusive Education Coordination Committee}

To address this, SSI (now renamed Able Disabled All People Together (ADAPT)), set up the Inclusive Education Coordination Committee (IECC) to initiate and monitor the inclusion of disabled and non-disabled children into mainstream schools. A team comprising teachers, therapists, social workers and researchers provided support to the partner schools attended by the students.

The IECC's role was to identify the students whose progress was to be followed; provide the inputs needed to support inclusion; and research the perspectives of the various stakeholders. It found that the key barriers to inclusion were in attitudes, access, curriculum and class size, training and support systems.

Based on this analysis, the IECC provided support that included:

- Orientation programmes for mainstream schools;

- Preparation for inclusion for disabled students, their parents, peers and staff;

- Dissemination of information on the availability of state board concessions for children with special needs;

- Arranging for the provision of writers for examinations;

- Guiding the mainstream schools on curricular modifications and assessment techniques (based on state board concessions);

- Counselling support for disabled students and their parents;

- Evaluating, modifying and designing furniture and mobility aids adapted to the requirements of the child; 
- Identifying physical barriers such as inaccessible buildings and toilets;

- Designing simple modifications such as ramps and grab bars and simple modifications for toilets;

- Sharing with teachers tips on classroom management and strategies in inclusive education;

- Providing physiotherapy and occupational therapy that is unavailable to any disabled child attending a mainstream school.

- Students can access therapy services at ADAPT centres.

The strategies outlined in the culturally appropriate policy and practice (CAPP) programme formed a basis for the technical inputs required by the mainstream schools. SSI also developed CAPP resource material, that focuses on putting inclusion into practice through change at three different levels: ${ }^{254}$

- CAPP I (the whole policy approach to inclusive education) is on the macro level of policy, legislation, political culture at local, state, national and global level;

- CAPP II (the whole community approach to inclusive education) is on the mezzo level of community workers and local administrators and bureaucrats;

- CAPP III (the whole school approach to inclusive education) is on the micro level of classroom and school values, culture, policies and practice.

ADAPT has also produced the 'How To' series of flip charts, manuals, CDs, audiovisual material and films. Over ten years, the IECC has provided resource support to all the key stakeholders, the main recipients of which have been mainstream schools.

Some issues the IECC has addressed are:

1. Mainstream schools were reluctant to admit children with communication difficulties.

2. The raising of issues related to inclusion by schools, based on the challenges they faced, rather than by individual parents and students.

3. Students included in mainstream schools have found it difficult to cope with the academic pressures.

Some issues in developing inclusion

1. The attitude of teachers has to be addressed periodically. It is more sympathetic than empathic. One child was not permitted to use the lunch room with the other children since the school authorities were afraid she would fall, so she remained behind alone in her class. The music teacher brought her to the front and favoured her, creating envy among her classmates. The IECC met the school authorities and explained the philosophy of inclusion. One of her friends began to take her to the lunch room. She also sang along with the others in a group.

2. The school identified for $A$ was disabled friendly and open to inclusion. She was included at the primary level. The principal, teachers and parents had positive attitudes and were given an orientation briefing. However, after a 


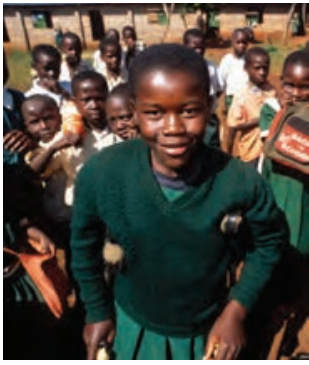

Joining in activities at a school in Oriang, western Kenya. Credit: Olav A Saltbones, UNESCO while, parents reported that they and $A$ were not happy and wanted to return to a special school. Members of the IECC found that the teacher found it difficult to understand her speech, so the child was frustrated and ignored. The principal and staff were counselled by IECC members and $A$ continued in the school.

3. When they are informed about the concessions granted by the SSC (Secondary School Certificate) Board, teachers often say these are for the school leaving exam in Grade X. It needs to be explained to them that these should be granted to all grades throughout the school.

The IECC now provides an child-centred orientation session to the mainstream school prior to inclusion; whenever possible, the parents of the child and the management are included in this.

A regular follow-up is maintained, especially in the first year and any challenges that arise are directed to the appropriate member of the team. Arrangements for remediation, therapy, psychological inputs or meetings with teachers are made by the social worker.

This empowerment of the mainstream schools by a continuum of support has led to a slow process of taking ownership of the inclusion. Some schools have taken their own initiatives in making the adjustment process easier. Staff at various levels, from the principal to ancillary staff, have contributed in their own way to making situations more comfortable for included children.

\section{Box 7.10 Oriang, Kenya: Developing an inclusive environment}

Leonard Cheshire Disability has been working with the Kenyan Government and a higher education establishment to retrain teachers and support a pilot inclusive education programme in five schools in Oriang, Western Kenya since 2001. The project benefits 2,200 children, 174 of whom have minor to severe impairment (mainly low vision, physical disabilities, epilepsy or learning impairment). A few have hearing difficulties. Many children have intellectual impairments caused by malaria and lack of access to treatment. More recently, over 700 disabled children have been included. Since 2007, the project has been extended to 300 schools in Kisumu Province.

Through its regional training and development programme, LCD provides technical and financial support for the project. Its east and north Africa strategy highlights the promotion of inclusive education, with a shift from longterm residential support to community-oriented activities. Support is provided to Oriang through two technical staff experienced in inclusive education.

Teachers from lower primary classes (and headteachers) have recently been trained in using an approach that features African culture to language teaching. They are encouraged to incorporate positive aspects of African culture and tradition in primary school literacy and language studies. With an initial focus on oral culture, teachers can create enjoyment in language and literacy learning through artistic conversations (one person acting more than one role in story telling), puns, tongue twisters, riddles, proverbs, folk tales and songs. 
Under an agreement with the Kenya Institute of Special Education (KISE), Oriang teachers are receiving ongoing in-service training leading to KISE certificate and diploma qualifications. The course includes distance learning during term time and meetings with tutors in the holidays. This model is the first of its kind in Kenya to incorporate inclusive education. The results of a survey by $\mathrm{LCl}$ in 1999 played a significant role in the design of the course. Fifteen teachers went on an in-service diploma course in inclusive education, which included sign language, Braille and the use of teaching and adaptive aids.

The two biggest challenges were the cultural aspects and feelings of hopelessness. The wider community held the view that having a disabled child was a curse and made their parents objects of pity and social welfare. Through community meetings (barazas), funeral gatherings, church services and youth theatre, a community project educated local people about disabilities and helped to change negative attitudes. The community is now much keener to find practical ways to adapt the environment for the benefit of disabled children. Attitudes to schools were also tackled. Parents had abdicated their parenting roles to schools, instead of working in partnership with them. The wider community believed that the role of developing schools belonged to parents whose children were enrolled and the teachers. This is now changing.

The project has achieved these changes because parents of disabled children have positively accepted their children and parents who do not have children with disabilities are now willing to let their children mix with disabled children. Despite the poor infrastructure, parents and siblings are carrying their severely disabled children to school on their backs and community members are volunteering their time and meagre material resources to improve school facilities. In the interest of sustainability, the project is run by a management committee from the local community, and the committee has been trained in community project management.

Using child-to-child principles, the project has been able to disseminate key messages through participatory theatre, story-telling, music and poetry.

A central resource centre has been established which provides specialist support for schools and families. This has a library, training facilities, a therapy area and a communications unit. In future it will offer internet facilities. It was decided that a central resource centre was not sufficient, so each of the five schools also has a small resource point offering a mini-library, access to play materials and teaching/learning resources, including materials made by pupils and teachers.

LCD has documented the process of inclusive education and how it has changed the lives of so many - not only disabled children, but also their communities. It is intended to produce a newsletter and a video documentary. Both will include stories of human interest and lessons learned. It is planned to use these for education, sensitisation and mobilisation of key players, including the Ministry of Education. In this way it is hoped to influence change at the levels of policy-making, teacher education and the community. Leonard Cheshire International is now using this model to develop inclusive education in Botswana, Malawi, Pakistan, Bangladesh and India. ${ }^{255}$ (See DVD 1.)

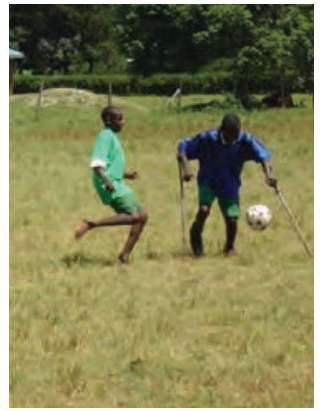

Playing football at a school in Oriang, western Kenya.

Credit: Leonard Cheshire DISABILITY 


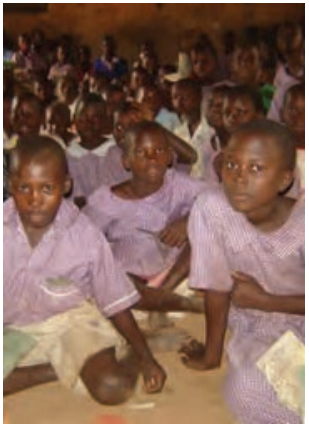

Children at a school supported by Leonard Cheshire Disability in Uganda.

Credit: Leonard Cheshire DISABILITY

\section{Box 7.11 Kenya and Uganda: Developing inclusive education}

The Nyanza Inclusive Education Programme (NIEP) ${ }^{256}$ is designed to meet the educational and developmental needs of disabled children by facilitating their inclusion within mainstream schools and the wider community.

Currently the programme has adapted ten primary schools in ten districts in Kenya's Nyanza province, namely Siaya, Kisumu East, Kisumu West, Kuria East, Suba, Rachuonyo, Migori, Kisii Central, Nyando and Bondo. Over 180 teachers have been trained on the inclusive education approach and 933 disabled children have been assessed and are enrolled in the project primary schools.

In Mukono and Budaka districts in Uganda, 20 schools are being supported by LCD and each school has a child-to-child club.

- Teaching and learning: Inclusion promotes child-centred learning. Children support each other in all areas. Older children use their artistic skills to make learning materials for younger children or their disabled peers. Some disabled children are good at certain subject areas such as mathematics and so they support their non-disabled peers.

- Co-curricular activities: The clubs promote drama, singing and poetry, where children can discuss the issues that affect their daily lives.

- School life: Children work in clubs to support each other by ensuring health issues are attended to such as washing hands after going to the toilet.

- Links between school and community: Creating awareness and sensitisation on disability issues is carried out during inclusive education and child-tochild days. These special days allow the children to interact and inform their communities about what they have learnt and showcase their capabilities.

- Community activities outside school: In the community, children help to identify disabled children who are not accessing education and report back to community health workers. ${ }^{257}$

The five-year expanded programme was launched in July 2007 by Hon. Beth Mugo, Kenya's Assistant Minister for Education. It will build on the gains of the original Oriang pilot project and focus on policies influencing teacher training and building the capacity of parents and local communities to lobby for policy changes, in partnership with Kenya Cheshire Services, Maseno University, Kenya Institute of Special Education and the Ministry of Education.

\section{Box 7.12 Shire Highlands, Malawi ${ }^{258}$}

A study of provision for disabled children was conducted in Shire Highlands Education Division. The division covers four districts: Mulanje, Phalombe, Thyolo and Chiradzulu. In each district, five schools were selected from one educational zone. The study targeted headteachers, mainstream teachers, disabled and non-disabled learners, primary education advisers, school management committees, village development committees and community development assistants. 
Currently, special needs education services are provided through special schools and resource classroom centres within mainstream schools. However, the numbers of learners with special educational needs cannot be accommodated in the small number of service centres. According to the Ministry of Education's Education Management Information Systems (EMIS) in 2007, approximately 69,943 learners with special educational needs were identified in Malawi primary schools. This may not reflect the actual number of learners with impairments because the education system does not have formal assessment tools for the identification of impairments. There are only 650 SEN teachers equipped with the knowledge and skills to provide additional support to pupils. In 2001 the government committed to a policy investment framework which included the provision of enabling environments for learners. As this study has shown, the problem is how to turn policy into practice.

When the responses of disabled learners and non-disabled learners were compared, it was found there were a small number of disabled learners in every school and class. They have integrated well into the schools, so that learners are used to supporting each other. However, interaction between teachers and learners is almost non-existent. Disabled learners receive care and attention mainly from their peers. The study revealed the challenges that teachers, disabled and non-disabled learners face in schools. These included:

- Lack of knowledge and additional skills in teaching disabled learners: in the 20 sample schools there were 189 teachers, but only four specialised in special needs education;

- Inadequate teaching and learning resources;

- Inadequate communication skills of teachers and learners in schools;

- Frequent absenteeism from school by learners;

- Negative attitudes by the teachers and the community towards disabled learners;

- Lack of interest and commitment towards education by learners;

- Inaccessible school infrastructure;

- Lack of assistive devices.

\section{Recommendations}

The baseline study team made the following recommendations:

- Need for sensitisation of parents, teachers, learners and school management committees on disability issues at school and village level;

- Provide in-service training for all mainstream teachers and primary education advisors on inclusive education;

- Rehabilitate and adapt the existing school classrooms, sanitary and recreation facilities to make the accessible;

- Provide different types of assistive devices to assist learners with mobility, hearing, and communication, sight, writing and sitting problems.

Despite government intentions, this sample study suggested there was 
Dribbling past the opposition in Oriang,

Kenya.

CREDit: Gideon MendeL, LeONARD CheshiRe Disability

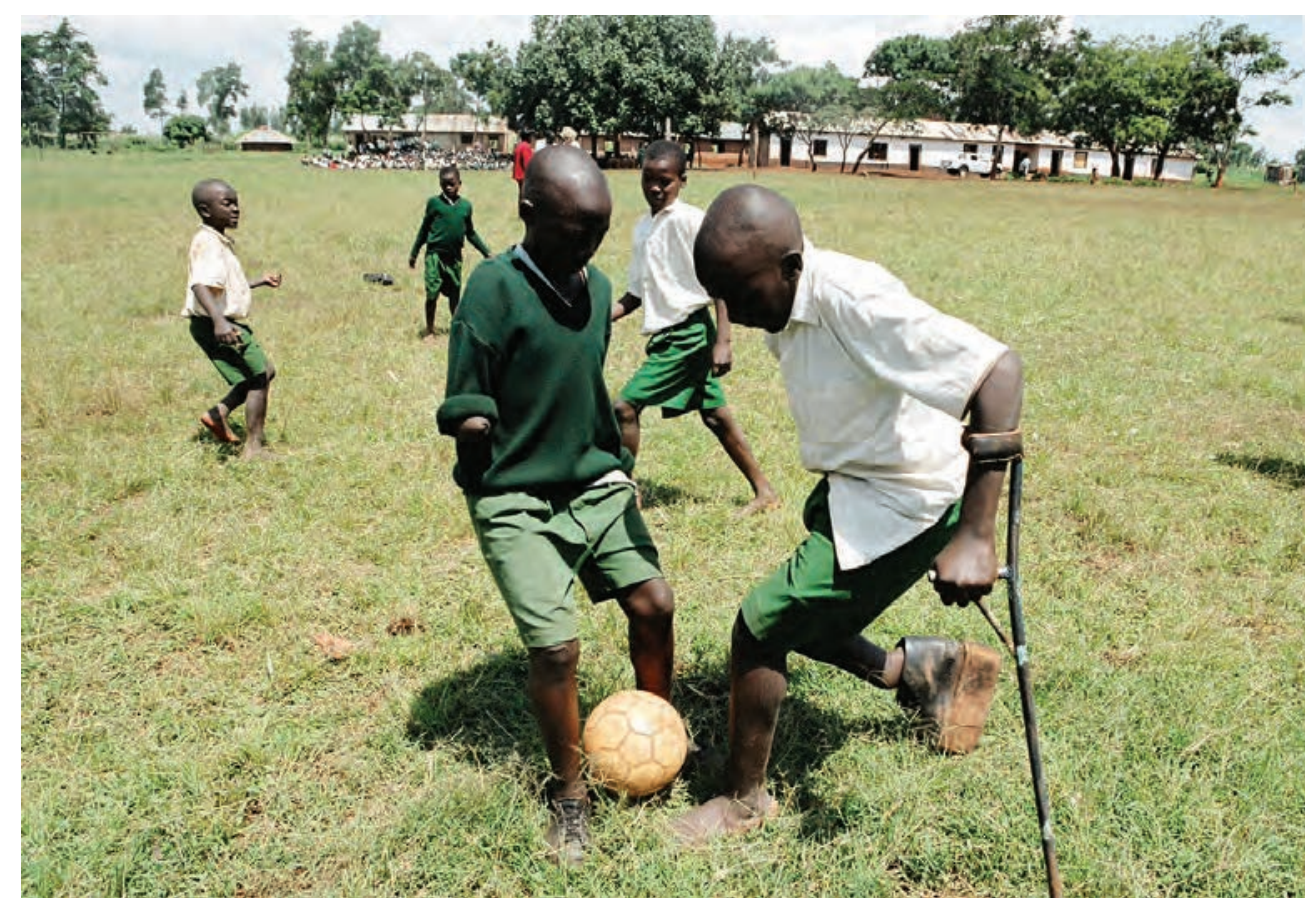

integration rather than inclusion; however, it showed that teachers were aware of their inadequacies and need for training and additional resources to transform the situation and introduce inclusion. There seemed little evidence of the integration of children with intellectual impairments.

\section{Box 7.13 Mpika, Zambia: Using child-to-child methods}

In the Mpika Inclusive Education Programme only a small number of teachers had special training. The teachers were used to meeting regularly to share experiences and solve their problems, both within individual schools and between clusters of schools. With the support of the teachers responsible for providing in-service training, the teachers have gained confidence in their own expertise and developed their own locally appropriate solutions. Previously, they relied on specialist teachers to work with children identified as having special educational needs and disabilities (Miles et al., 2003).

Mpika has a strong history of teachers communicating health education messages through child-to-child methods and of incorporating these activities into Maths, English, geography and social science lessons. In the mid-1990s they began to use the same methods to explore community attitudes to disability. Children were asked to conduct a community survey to identify outof-school children and find out why they stayed at home. This was very successful in raising awareness and encouraging children who would otherwise have stayed at home to attend school. It was also a very effective way of encouraging the parents of some of the children to reduce their domestic workloads to enable them to attend. The project developed friendships, encouraged children to travel to school together, arranged home visits at weekends and provided support with academic work.

As a result, teachers in Kabale primary school, 600 kilometres from Zambia's capital, Lusaka, have radically changed their style of teaching. This has paved 
the way for the inclusion of children with learning difficulties. When the school opened in 1966 it had 40 children and one teacher. Today, because of increased job opportunities in the area, it has almost 2,000 children and 40 teachers. The school is a resource centre for the child-to-child programme. Staff are encouraged by the school administration to promote children's participation in their own learning and the equal participation of pupils, parents and teachers in education, using the following strategies:

- Introducing children to their rights and responsibilities;

- Co-operative group learning and problem solving;

- Encouraging pupils to question traditional sources of knowledge;

- Evaluation of the learning process by both pupils and teachers;

- Involving pupils in decision-making;

- Putting a strong emphasis on gender equality;

- Encouraging parents to participate in their children's learning.

The combination of these approaches has encouraged ownership of the school by the community - an essential part of the inclusive process. As these changes were being introduced, the Ministry of Education, with donor support, arranged for a small unit for children with learning disabilities to be built at Kabale school, without prior consultation with the staff. There was to be a specially qualified teacher who would teach five children in the unit. Meanwhile the child-to-child programme had identified 30 children with learning disabilities who had been excluded from school. There followed a difficult period of negotiation, but the school succeeded in taking in all 30 children. Co-operative teaching methods and child-to-child methodology enabled them to be taught with their peers. Gradually, the unit has been transformed into a resource centre used by all the teachers.

The ideas developed at Kabale have been shared with 17 schools in the surrounding district and regular meetings are held at which teachers share their experiences. Kabale's success in raising academic standards, attendance rates and including children with learning disabilities has been studied by universities in Zambia, the UK and the USA. It is likely that the lessons learned will trickle up and influence change at policy level. ${ }^{259}$

\section{Box 7.14 UK: Friendship comes first}

Davigdor Infant School in Hove, East Sussex, is the main placement for William, a child with cerebral palsy who cannot speak with his own voice. Vita, Reagan, Lucy and Natasha are William's particular friends. Vita said that Natasha is usually the leader and helps him most. She is the one who can interpret what he wants. She can see his eye movements. Natasha's Mum says, 'William has been fantastic for Natasha. She began by being frightened of him, but now he is one of her closest friends. She now understands that he is no threat, just has different needs. It has helped her self-esteem and confidence. When she knows William will be in school, she gets up and says "It's a William

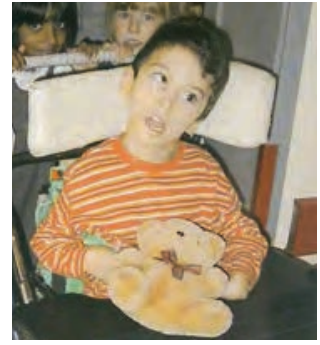

William at Davigdor Infant School, Hove, UK.

Credit: Alliance for INCLUSIVE EDUCATION 


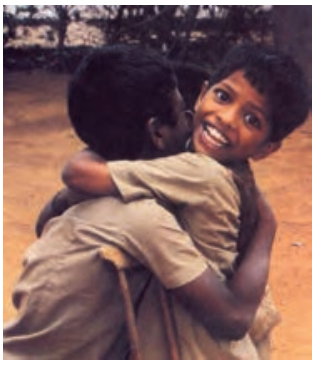

Friendship and acceptance is the key to learning together. Cerdit: Carlos Reyes Manzo

Dominic and Kirsty at Kirkhill Primary School, Scotland. CReDit: Alliance FOR INCLUSIVE EDUCATION day today". She never wants to miss school when he is there, even when she is ill. They have a special friendship.'

Young people always say that having friends is the most important thing about school. Friendship between children who are considered 'ordinary' and those who are considered 'different' teaches everyone important lessons about being human, about how we all need each other and how we all have gifts to give.

'What we most enjoy at playtime is when we push William up the hill in his wheelchair and come down really fast - we run down all holding on because we must not let go or he will roll off and get hurt. We hold on really tight in case he gets frightened. We enjoy reading with William. We hold out two books and he looks at the one he wants. We follow his eyes. He likes Kipper books. Lucy and Vita hold the book and turn the pages, and Natasha reads the words. When he is out of his wheelchair he lies down to take part in activities and we lie down with him. When William goes to soft play, a group of us go with him and we all roll around together. The best thing about having William in the class is his hugging and giving big cuddles' - Pupil, Davigdor Infant School

At Cottesbrooke Infant School, Birmingham, they have a friendship stop in the playground. Six children wear a special hat to show they are playground buddies. They look out for children who might be being left out or bullied.

At West Bridgford Junior School, Nottinghamshire, young people can ask to have a PALS group where they can talk about things that may be worrying them. Carol explains that she used to have arguments with her friends: 'We used to have misunderstandings that would go on for days, now they only last for 20 minutes. The PALS group helped us to talk about the problem and think of ideas of how to help.' One boy had been having difficulties getting along with others. One of his friends in the PALS group explained: 'It's like sometimes you fall out of the boat into the ocean and you're floating around. We're your lifejackets. All you have to do is reach out and put us on.'

'I have a friend who is disabled. He is called Dominic. We were in nursery together. He joined our school this year and we got really close. Sometimes I feed him at lunchtime. You know when you meet that person they'll always be a friend ... I understand the way he feels, he understands me and the way I feel. He does things to cheer me up ... he'll do something funny, make a face to make me laugh.' Kirsty, Kirkhill Primary School, Scotland

Sometimes young people need help to make and

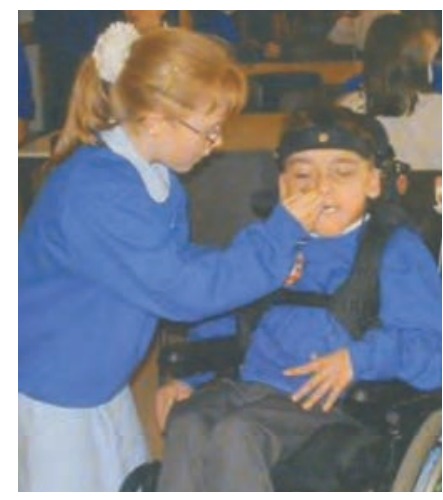
keep friends. A circle of friends can be set up with the support of an adult and will involve bringing a group of volunteers together to think about the inclusion of a particular classmate who might be lonely, afraid or in danger of exclusion. The group meets regularly and has supervision sessions with an adult facilitator.

At Bluecoat School, Arousha has a circle of friends who meet every week. One of the boys in her circle commented: 'Arousha, she feels like one of us instead of left out. She is a child of our form and our friend.' 260 


\section{Box 7.15 Vanuatu: Child-friendly schools}

In Tafea province, Vanuatu, a joint Ministry of Education and UNICEF basic education project has been set up that focuses on including every child.

There are six pillars in child-friendly schools:

- Including every child

- Teamwork with parents, teachers and students

- Child-friendly leadership and administration

- Gender-responsive education

- Effective learning through effective teaching

- A healthy and protective environment

The project began in 2002 and focused on 12 schools. It brought children who did not access education into school by using community radio and home visits. It was not helped by the destruction of schools by cyclones and high teacher turnover, but the team spirit built over three years got 375 disabled children into school and supported more than 180 children who were already attending. Schools became cleaner, the curriculum was made more relevant, and parents and the local community became much more engaged in education. The programme is now being rolled out to other parts of Vanuatu. ${ }^{261}$

Piau-Lynch (2007) describes how there has been an increase in the enrolment of children with disabilities in schools. In 1998, only 35 children with disabilities were enrolled: but by 2004, when the Ministry of Education collected statistics on students with disabilities, 2,012, or 5 per cent of children with disabilities, out of a total of 38,960 children were enrolled in primary school (Ministry of Education, 2005). This doubled to 3,963, or 12 per cent of children with disabilities, out of a total of 33,268 children in secondary schools in 2007. By senior secondary school, only 251 children with disabilities, or 5 per cent of the total population of 4,804 children, were enrolled. ${ }^{262}$ In addition, a further 163 disabled children were not attending early years provision and 247 disabled children were not attending primary school due to barriers in 2007. The number of disabled children transitioning to secondary school has gone up from 2004 to 2007 in five districts, but in Torba, the sixth district, none of the disabled children identified in primary school made it to secondary. 11.91 per cent of the primary enrolment were identified as disabled in 2007, but only 7.4 per cent of the secondary enrolment.

Following the analysis, the following strategies were put forward to the Ministry of Education:

- Understand the concept of inclusive education at all levels within the education system;

- Establish a Division of Inclusive Education with its own budget in the Ministry of Education;

- Rewrite the draft inclusive policy in consultation with parents, disability organisations and representatives from the health, public utilities and 


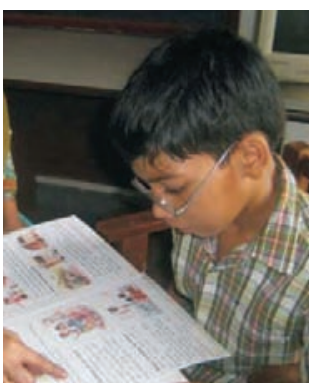

Learning to read at a school in Mumbai. CREDIT: Confluence infrastructure sectors to ensure that inclusive education is understood;

- Develop a ten-year plan of action on inclusive education and declare 2008-2017 as the Decade of Inclusive Education, when strategies would be implemented to achieve an inclusive education system in Vanuatu;

- Identify one province or one location to introduce programmes on inclusive education;

- Collect qualitative as well as quantitative statistics;

- Create a clearing-house for data on inclusive education.

At present what is happening is integration, with children fitting into the existing system; this is why some disabled children cannot attend school. What is needed is training for all involved in education led by the Vanuatu Society for Disabled People on the paradigm shift to inclusion and its impact on education, as outlined in Article 24 of the UNCRPD.

\section{Box 7.16 Mumbai, India: Co-operating with a local authority}

Pratham, a Hindi word for pioneer, is an NGO established in Mumbai ten years ago with the aim of achieving Education for All. The project is a collaboration between the Mumbai Municipal Corporation and a group of volunteers, with financial support from UNICEF.

It began by training teachers in support of a pre-school initiative. Other needsbased components, such as the provision of mid-day meals, extra coaching for students who faced difficulties in learning and incentives for girl students, were added later. It soon became evident that further financial resources were needed to sustain its activities. Pratham reaches about 90,000 children in schools and slum communities, teaching them to read, write, do basic Maths, speak English and how to prepare for the state government class IV scholarship exam. In 2010, 96 scholarships were awarded to pupils in Pratham classes (8,491 children appeared and 3449 (41\%) passed). Pratham's Library Programme introduces children to a range of interesting books and reaches out to about 77,000 children in Mumbai itself. Pratham is also instrumental in rescuing and repatriating children from the factories of Dharavi and other parts of Mumbai, which are now largely child labour free. So far, over 45,000 children have been repatriated. ${ }^{263}$ Pratham now has a national focus and concentrates on rural non-attendance and drop-out and the Read India literacy and numeracy programme.

\section{Box 7.17 Quebec, Canada: Parents' action for inclusive education}

Parents in Canada have pressed for inclusive education by challenging the legality of segregation in the courts, using education legislation, human rights arguments and particularly the Canadian Charter of Rights and Freedoms, which enshrines the right to equality for all citizens. The Quebec Association for Social Integration has been particularly successful in lobbying for change and 
has developed guidelines for parents on how run effective campaigns. Parents are encouraged to:

- Talk about issues affecting them;

- Discuss and find common viewpoints;

- Develop a standard position statement and compile a list of frequently asked questions, and answers to them;

- Understand the benefits of school inclusion for other learners, the importance of a continuum of health, welfare, labour and education services, and a successful transition to the world of work.

Parents have been helped to create and strengthen alliances with other groups. They are encouraged to write up their experiences of participation in schools and those of others through printed case studies of successful school inclusion. Parents have also worked with trainee teachers, telling them about their experiences in order to promote educational change.

\section{Box 7.18 India: Vidya Sagar, Chennai}

Vidya Sagar, Chennai is a movement and a statement of faith. Every child has a right to education.The inclusion cell at Vidya Sagar helps students to access this right in educational institutions. Vidya Sagar trains educators in six blocks, reaching out to 400 schools and 1,500 disabled children in mainstream schools. Under the programme, 100 pupils are receiving inclusive education in 30 schools and eight students are now in different colleges in Chennai. The Sarva Shiksha Abhiyan programme has enabled Vidya Sagar to help 1,424 disabled students to attend regular schools, and to involve 174 students in early intervention programmes and 12 students in alternative schools. Students' participation in all the activities organised by the educational institutions is facilitated by assisting in academic studies, physiotherapy, communications, counselling and financial support, and providing furniture, orthotic and communication aids, and learning materials.

All students receive support

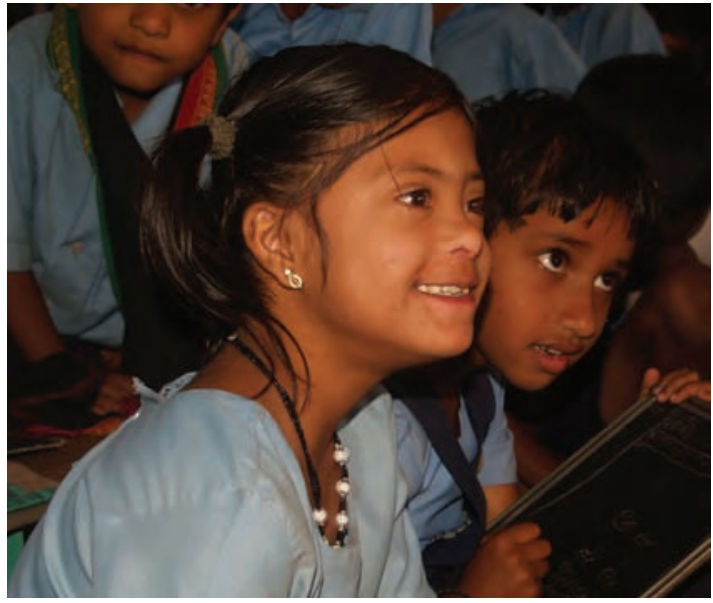
services according to their needs. SSA students are supported by 12 special educators and a physiotherapist appointed by Vidya Sagar. The specific needs of these students are also met at the six resource rooms created for each block in the SSA programme. Recently a vision centre and an employment centre have been added. The creation of six inclusive playgrounds create opportunities for disabled and non-disabled children to play together. The equipment also makes therapy an enjoyable activity. Community participation is vital, and the inclusion cell
Children with learning difficulties included at a school in Chennai.

Credit: Leonard Cheshire DISABILITY 


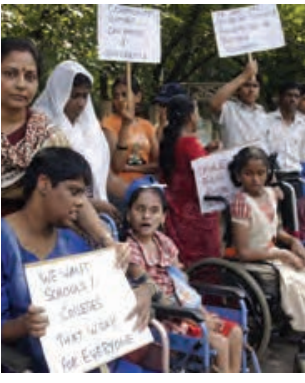

Vidya Sagar:

Demonstrating for inclusion.

THE HINDU, HyderABAD

organises training programmes for teachers, and workshops for students, parents and volunteers. Ten training programmes are conducted for 150 teachers and five workshops for parents each year. Some of the parents have volunteered to assist students in their academic studies, and workshops have been held for students to enable them to understand the abilities and needs of their disabled peers. INScribe is a volunteer support programme. The inclusion cell has been working towards creating opportunities for inclusion and sustaining it. ${ }^{264}$

\section{Box 7.19 Uttar Pradesh, India: Sikshit Yuva Sewa Samiti}

In 2003 UNICEF evaluated a number of inclusive education projects in India, using the Index for Inclusion as a framework, with observations and interviews.

The district of Basti is the most 'backward' region in Uttar Pradesh in northern India. It has a population of about 1.8 million, 40 per cent of whom are scheduled caste/tribes, 20 per cent religious minorities, 30 per cent other 'backward' classes and 10 per cent higher castes. Almost 80 per cent of local people live below the poverty line. Lack of industrialisation means that there are few employment opportunities.

Sikshit Yuva Sewa Samiti (SYSS) was started in 1994 to provide employment for young people and to work for the betterment of the community. At the same time, the Danish Embassy selected Basti for a pilot project for the rehabilitation of blind people. As a precursor to this project, SYSS trained three people at Gramoday Vishwavidyalaya in Madhya Pradesh as special educators for the blind. Initially, 16 children were integrated into schools and about 25 field workers were trained in community-based rehabilitation. At this point, the organisation specialised in the education and rehabilitation of children and adults with visual impairment. Now, SYSS employs 37 teachers trained to teach children with various impairments. This intervention started in 1999 in one block in Basti district and was extended to a second block two years ago. Previously, only a few physically impaired children were enrolled in school and they had no assistive devices apart from those manufactured at home. Children with visual and hearing impairments were not enrolled. The success of the project is evident - all disabled children are now enrolled in school. A few children with severe impairments have been enrolled in special schools outside the district. In 2010, SYSS helped include 12,000 blind children in mainstream education and set up a centre for the education of deafblind children

There is now an inclusive culture in the area. Parents, peer groups, the community, school authorities and teachers support inclusive education. Teachers have undertaken a five-day awareness programme and have shown remarkable readiness to enrol and teach disabled children. The district's basic education officer is enthusiastic about further training of teachers in the management of disabled children.

Schools are close to the community, and disabled children journey to school with the help of other children. The physical infrastructure of new school buildings includes ramps and accessible toilets. Old school buildings do not have such facilities, so children and teachers help disabled children. Old 


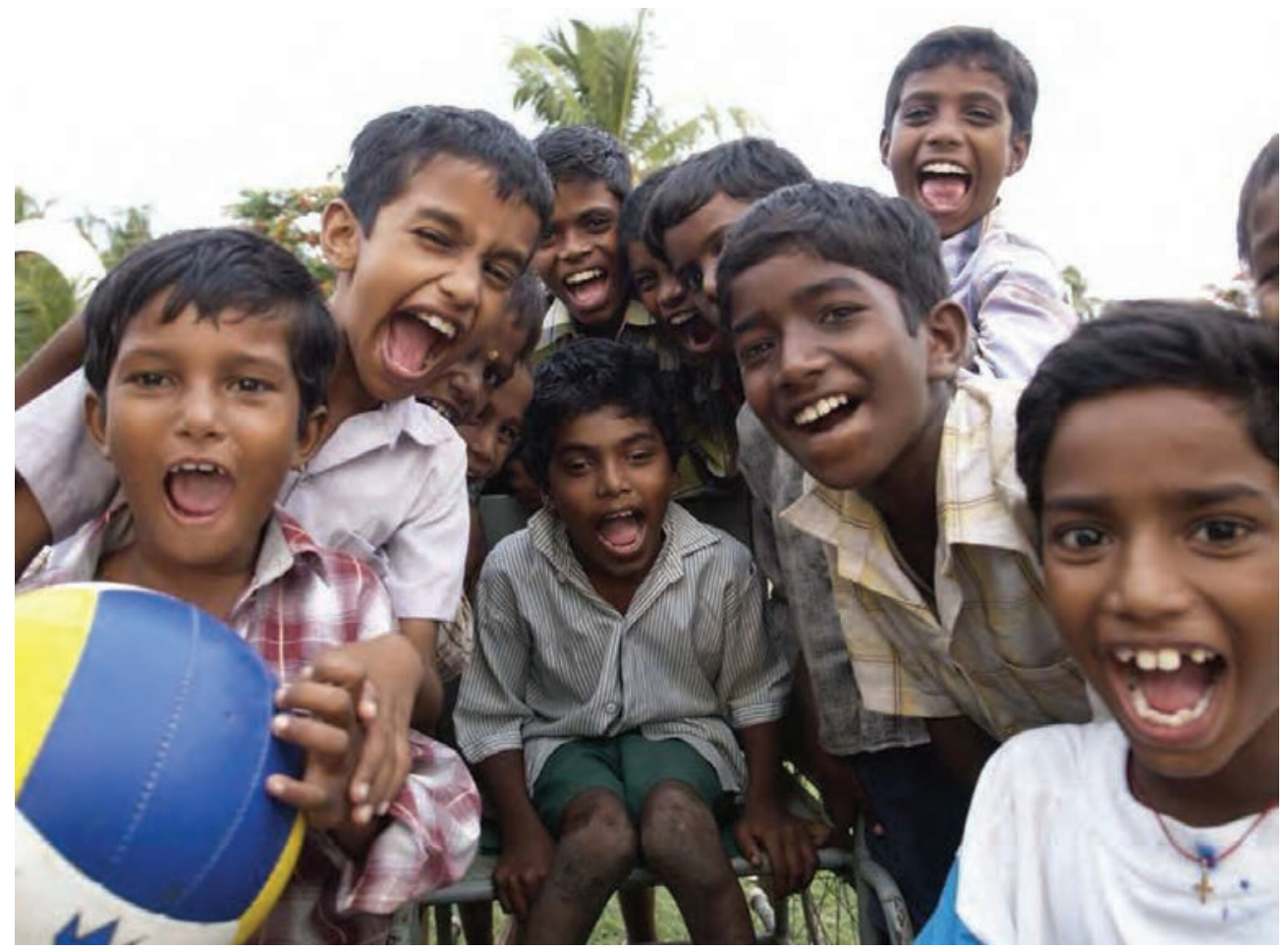

All boys together in

Kerala.

SUDHINDRA CN/LEONARD

CHESHIRE DISABILITY

schools are being modified to provide better access. The teacher: student ratio is high, with 70-100 students per teacher. Most classes are held outdoors and there are a large number of single teacher, multigrade schools. ${ }^{265}$

\section{Box 7.20 Kerala, India: Integrated education}

Since 1992, the Integrated Education for Disabled Children (IEDC) scheme has been implemented throughout Kerala. About 8,000 schools cater for 27,350 children with special needs. They include 1,700 who are visually impaired, 5,650 who are hearing impaired, 13,000 who are orthopaedic impaired and 4,000 with learning difficulties. The Ministry of Human Resource Development supports the local IEDC cell under the Directorate of Public Instruction, and up to 2007 Rs33 million was provided. There are approximately 56 resource rooms and one vocational rehabilitation centre. Over 200 special teachers are working under the scheme.

The IEDC component of the district primary education programme (DPEP) was initiated in 1994 and has been implemented in six districts. Malappuram District was chosen for this study because it is the largest, with 22,000 teachers and 800,000 children in classes 1-12. Resource books and teachers' aids were developed in the first three years. Since 1998 identification has been carried out in all blocks, and aids and appliances have been distributed. There is no provision for surgery or other treatment.

Orientation and training programmes of varying durations have been conducted for teachers, administrators, parents and the public. There are 15 resource centres and 40 resource teachers under the DPEP and 17 under the IEDC scheme, who all work together as a team. Multigrade learning centres with a single teacher have also been set up. In Malappuram, 14,146 children with 
special needs have been identified and enrolled in normal schools, and about 522 children have received aids and appliances.

The programme has been generally effective. Classmates of children with special needs enjoy their company and help them in many ways. Teachers are happy that children with special needs learn well. The curriculum could be more child friendly and general teachers would like more training in handling children with special needs. The supply of resource teachers is limited. In Malappuram District, convergence is taking place between IEDC and the DPEP. Parentteacher associations and local committees play a major role in mobilising resources. However, this kind of convergence is not taking place in other districts. Children with visual and hearing impairments are still studying in special schools, and will eventually be enrolled in mainstream middle or high schools. Although the models presented here can cater for the needs of all disabled children, most children with special needs are still waiting for some kind of service. There is a need for networking and sharing to accelerate the availability of services for unreached children. ${ }^{266}$

\section{Box 7.21 Zambia: Supporting educators in inclusive classrooms}

Zambia's Northwestern Province is a rural area where general schools are flexible and can provide for children's diverse needs. In 1996, the Ministry of Education adopted a policy statement, Educating Our Future, and worked with donors from Ireland, Denmark and Finland on the Education Sector Support Programme to provide inclusive education. In 2001, the Ministry collected extensive data to provide a baseline from which to operate. The survey found that 7.6 per cent of pupils $(8,397)$ had special educational needs; 70 per cent of educators said they taught children with special needs and that they were working inclusively, but they did not have adequate tools or expertise. Thirtyfive per cent were then in mainstream classes, 49 per cent in special classes or units, 11 per cent in institutions and 5 per cent in special schools. Thirty-two per cent of all children of school age were not attending school. The terrain is difficult and the average distance between schools is $22 \mathrm{~km} .52,168$ children did not attend school. The reasons given for this were economic $(40.9 \%)$; long distance; (23.9\%); disability (22.4\%); illness (6.4\%); and other (6.7\%).

The Inclusive Schooling Programme relied heavily on the provincial organisation. Kabompo district, with ten primary schools, was chosen as the first area, and sensitisation and capacity building workshops were held. In 2003 the programme was extended to six more districts. Parents, teachers and administrators received training and this is ongoing. As donors withdrew, funding became more generalised over the whole sector. More parents wanted their disabled children to be educated in mainstream schools and teachers were more willing to enrol them.

Despite the persistence of traditional views, parental behaviour changed in favour of including their disabled children. Such projects show the need for long-term sustainability and greater emphasis on the empowerment and involvement of local disabled people and their organisations. ${ }^{267}$ 


\section{Box 7.22 Mozambique: Training more disabled teachers}

The Associação dos Deficientes Moçambicanos (ADEMO) is a national disabled people's organisation in Mozambique. To respond to the lack of qualified teachers in Mozambique and to address the exclusion of large numbers of disabled children from school, ADEMO is working with a teacher training college in Cabo Delgado in the north of the country to train disabled teachers.

The objectives of the ADEMO programme are to:

- Promote the right of disabled people to be educated;

- Educate teachers who have disabilities who can lead by their own example and be models for others;

- Create an educational environment where there is room for all;

- Promote the idea that people with disabilities can participate fully in the development of society.

In 2001, three disabled people from ADEMO became the first to receive a scholarship from ABILIS, a Finnish disabled people's organisation, to enable them to attend teacher training college and in 2003 they graduated. Four more students from ADEMO are currently participating in the teacher training course.

The disabled students improve the educational environment in the college and offer a practical example to other trainees that education is for all. They participate in all aspects of the school programme and in social activities.

\section{Box 7.23 Papua New Guinea: Teachers' views}

A 2006 study investigated primary school teachers' experiences of inclusive education in regular schools. The study was conducted in five districts of Enga Province, Papua New Guinea. Six primary schools were chosen and the project involved 77 teachers who responded to a questionnaire, 12 of whom were selected for interview. Data from the questionnaires and the interview transcripts were gathered and analysed for the study. The findings revealed that most teachers supported the idea of having an inclusive education policy and wanted to implement it. However, they indicated that a change was needed in the attitudes of teachers, peers, boards of management, and parents and carers to provide assistance for children with special needs. Most teachers felt that there needed to be more awareness of the principle and importance of inclusion.

Teachers' limited knowledge of teaching children with special needs was also highlighted. The teachers admitted they needed more training so that they could accommodate children with special education needs and teach them better. This shows that teacher colleges and universities need trained lecturers who can develop more courses in special education. Teachers expressed concern that school inspectors do not know enough about the inclusive education concept and argued that they also need to be trained, so that everybody can work together to implement the policy. Slow progress is being made with additional funding from AusAID. (See also Box 6.23.) ${ }^{268}$ 


\section{Box 7.24 Samoa: Inclusive education}

Senese Inclusive Education Support Services is an NGO that employs 54 people to champion inclusive education throughout Samoa. Children who learn together learn to live together. The organisation currently works with the Ministry of Education, Sports and Culture (MESC), National Health Service and the Ministry of Women, Community and Social Development (MWCSD) to change systems to allow more children with disabilities to have the very best opportunities to learn.

The Government of Samoa's 2009 draft national policy on disability sets out the following strategies: (i) greater classroom support for children with disabilities in schools; (ii) expansion of inclusive education in the curriculum division of MESC; (iii) up-skilling of staff; and (iv) reviewing the exam-based 'push-out' system in the context of children with disabilities.

Following the 2008 Pacific Disability Forum, AusAID and the Royal Institute for Deaf and Blind Children in Australia explored the scope for involvement in Samoa. Working closely with SENESE, MESC, MWCSD and others, it was agreed to design an inclusive education programme addressing the needs and priorities of children and young people with disabilities. The programme will be consistent with the Samoa Draft National Policy on Disability, MESC policy on inclusive education and the Australian Government's new disability inclusion policy for its aid programme. ${ }^{269}$ The programme also aims to increase the employability of Samoans, including those with disability, through qualityassured training in demand areas. As poverty increases as a result of the present economic crisis, the partnership will also support the establishment and funding of a targeted evidence-based school fee relief scheme, to support access for Samoan children through basic school education.

SENESE supports inclusion in the areas of deafness, blindness, learning difficulties and autism. Another NGO supports the inclusion of children with physical impairments. MESC has a mandate to encourage all schools to be inclusive. It is currently developing an inclusive education policy involving a broad consultation with every school in Samoa. The National University of Samoa sets compulsory papers on inclusive education for all undergraduate teachers on its BA course, and has an inclusive education post-graduate programme.

A new inclusive primary curriculum helps teachers identify learning styles and supports co-operative and interactive learning. Government ministers have welcomed the partnership with SENESE as a strategy to fast track development. The partnership has enabled over 160 pre-school, primary and secondary students with disabilities to be included. SENESE's outreach visit programme covers $\mathbf{7 0}$ government and mission schools where children with disabilities are included.

Samoa has been working on inclusive education since 2000 and in the last two and a half years has been supported by AusAID. SENESE has 'bitten off more than we could chew, learning how to chew, it tastes delicious. In other words we have seen such positive stories of change occur.'

SENESE has selected a number of top quality international partner NGOs who share a common vision of inclusive education. It recognises that inclusive 
education is about changing the system. It is a process or a journey - every journey begins with a first step.

What were our important first steps?

- It is crucial to empower families - because they have the highest motivation to make it work. An inclusive education programme that does not work with families will not achieve very much.

- Parents talking to parents is powerful.

- It is important to start work with families of very young children.

- Involving family members as teacher aids is an important step. ${ }^{270}$

\section{Box 7.25 Tanzania: Advocating for inclusive education}

In 2005, Light for the World (a European confederation of development organisations) and the Tanzanian Information Centre on Disability launched a four-year advocacy project, Inclusive Tanzania, in rural Mwanga District and in Dar es Salaam. It aims to strengthen the country's disability movement, hold the government accountable and raise public awareness about the rights of disabled people. Disabled people and those they work with define the project's priorities, develop strategies and carry out activities. Twelve local disability organisations formed the Inclusive Tanzania Consortium (MTAJU in its Kiswahili abbreviation) which 'owns' the project. There are now 14 disabled people's organisations and NGOs working together towards an inclusive Tanzanian society. The consortium calls itself MTAJU (mtandaowa Tanzania jummishi in Kiswahili).

To realise inclusive education, different actors must be addressed, for example government, district authorities, international organisations, community leaders, school boards, teachers, parents and children. MTAJU has created a steering committee, working groups and local community (ward) groups. In the rural areas, 11 ward groups involve disabled people, parents, teachers and children who identify as disabled people; ensure sufficient teaching and learning materials and assistive teachers; make the learning environment welcoming; organise events to raise awareness; and collect funds for physical access improvements. The work with families was crucial in encouraging them to enrol their disabled children in school and to become allies in their struggle for rights and education.

The ward level work is well-documented. Case studies are used in national and international advocacy for changes to laws, policies and development programmes relevant to inclusive education. Such work needs a large movement to be built from the bottom-up, not just activities by a few 'experts'. Disabled people need to assert themselves as experts through their personal experiences and to empower themselves. Inclusive Tanzania uses training, networking and 'learning-by-doing' to foster empowerment. Workshops on advocacy and inclusive education skills are run regularly by local and regional facilitators. MTAJU encourages information exchange between rural and urban participants, and between local, national and international advocates.

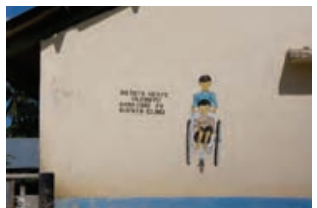

A mural in Tanzania illustrates the right of disabled children to receive an education. CRedit: MARCel OOSTERWIJK 
Empowering parents and disabled people's organisations. CREDIt: MTAJU

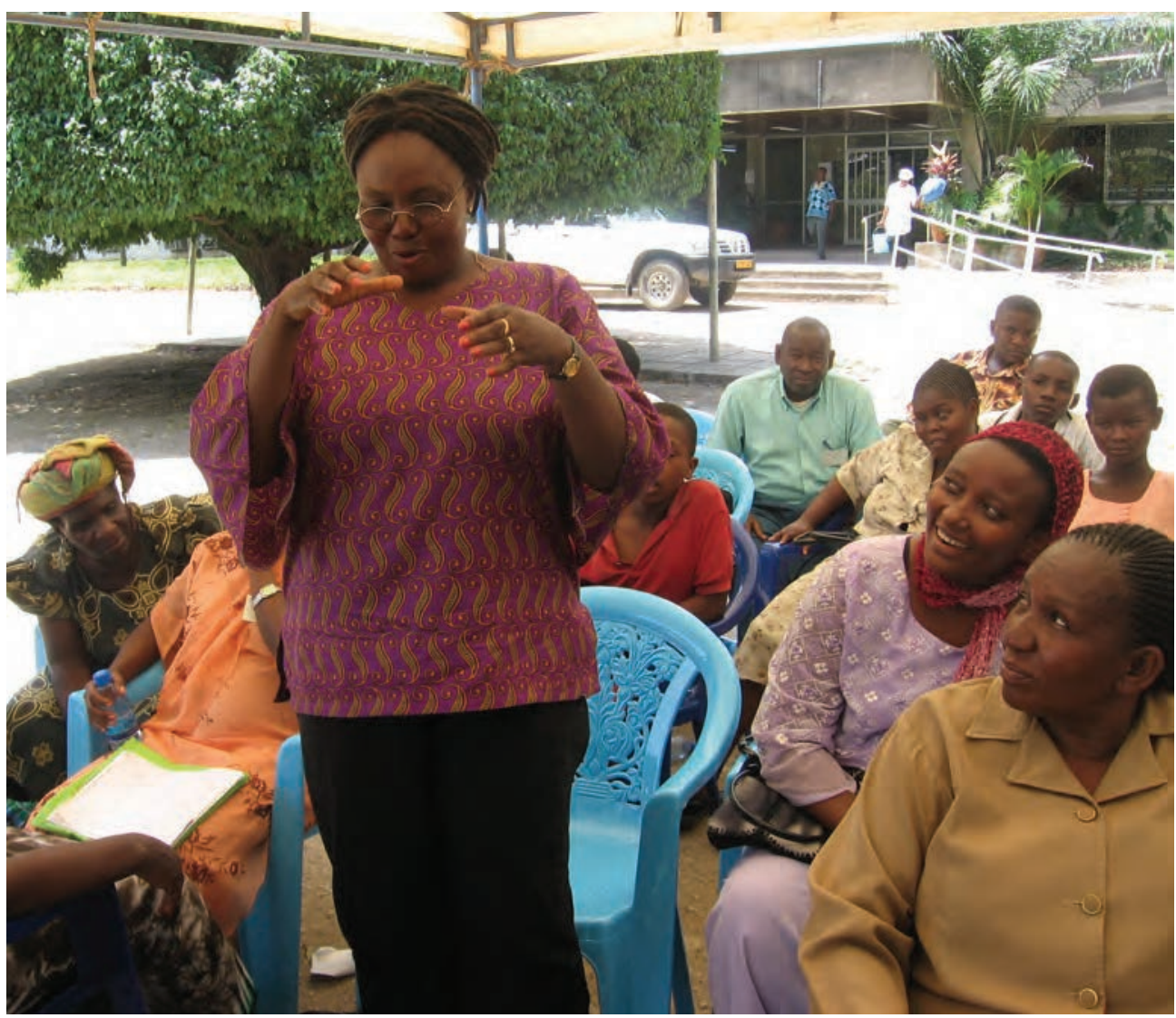

By 2010, 390 disabled children had been enrolled in 11 schools. MTAJU contributed to the development of Tanzania's new inclusive education policy by raising awareness through the media, lobbying politicians and taking part in public debates. MTAJU members lobbied parliament to ratify the UNCRPD, which it did on 24 April 2009.

The organisation helps to monitor school budget allocations at district level. Project members are becoming role models in society. There is improved unity and co-operation between organisations working on disability rights and inclusive education. For the first time, disabled people's organisations representing people with different impairments have come together to demand a rights-based approach. A manual is being produced recording the experience of the project in collaboration with the Ludwig Boltzmann Institute of Human Rights. Disabled politicians contested elections and there are now four disabled MPs. Media work and awareness-raising have been vital to the project's success. ${ }^{271}$

Scaling up has been successful, with the project making a major contribution to a national strategy on inclusive education, a new Disability Act and a new Education Act, all relying on the principles of the UNCRPD. The community has helped make schools accessible through contributions and voluntary work on classrooms, toilets and entrances. It has supported the development of 23 inclusive primary schools - 6 in Dar es Salaam and 17 in rural Mwanga, where the district government has decreed that all primary schools must be inclusive. The structures built by the project are continuing after its official end. 


\section{Box 7.26 Bushenyi, Uganda: Including deaf children ${ }^{272}$}

Bushenyi District Education Department is supporting 123 deaf children, registered in 14 units attached to primary schools, and six students in secondary education. This is a community-based initiative which has strong government commitment to teacher education, parent involvement and sign language development. In 2009 it was independently evaluated.

The Ugandan government has developed equitable education policies which prioritise girls, children from income-poor families and disabled children. This began in 1996 with universal primary education. Ugandan sign language has been formally recognised, there is a national Disability Act and the government has ratified the UNCRPD.

From 1984 to 2000, DANIDA supported a programme of early identification and formal education for disabled children throughout Uganda. However, when they withdrew, the Ministry of Education was unable to maintain resourcing at the previous level.

In 2000-2001 VSO Uganda examined ways of making more sustainable provision. They found deaf children and those with learning difficulties were largely left out. Based on these findings, in 2002 Bushenyi District Education Department began implementing a new primary level inclusive education programme. Key features were:

- In-service teacher training for unit teachers

- Five units for deaf children

- A policy that no deaf child should live more than $10 \mathrm{~km}$ from a special unit

- Teachers in the primary schools with units volunteered to receive on the job training in sign language.

In 2007 a community-based organisation, Silent Voices, was formally established, co-ordinating parents' group activities, and helping to support their fundraising, finance and management. Parents' group members meet, support each other, learn sign language and raise community awareness.

In 2009 an evaluation of the inclusive education programme was carried out. By this time there were 14 units educating 123 deaf children. The following successes, challenges and points for future consideration were recorded:

\section{Successes}

- Six pupils progressed to secondary education in 2009. All passed their first year exams; one came third in a class of over 100 children.

- Teachers in the units are on the district payroll - there is no separate financial arrangement for the inclusion of deaf children.

- The schools with units are government schools, so no fees are payable unless the child is a boarder

- Many teachers in the units now hold a diploma in special needs education. Teachers from the original five units have helped to train teachers in newer units. 
- There is a high level of commitment among parents and teachers; many had previously resisted the inclusion of deaf children in local schools.

- Community attitudes towards deaf children have greatly improved.

- The number of deaf children being brought to school continues to increase.

- The number of deaf students in Bushenyi District schools is four times greater than in the rest of Uganda, relying on units and deaf special schools.

- Deaf young people understand the value of education; many have been encouraged to aim for secondary education.

\section{Challenges}

- It has proved difficult to recruit deaf adults to help with the sign language training.

- Many children have very poor language skills and teaching staff are struggling to know how to respond.

- There is only one sign language interpreter for the six deaf learners in secondary education.

Future projects should consider:

- Involving the local government education department from the beginning, so that they have a sense of ownership, and include teachers' salaries and extra classrooms in education budgets;

- Starting with a small, pilot project to generate parent-led demand for deaf children to be educated;

- Involving deaf adults in service development and delivery. It is essential to pay careful attention to deaf children's language development, and sign language development in particular. This can be done by supporting teachers to learn how to develop children's language skills and involving deaf adults in the education of deaf children as role models for language development, including sign language..$^{273}$

\section{Box 7.27 Mpika, Zambia: Democratisation of the classroom}

Paul Mumba is a teacher in a village school who believes that inclusion is about human rights, social justice and democracy. He asserts that so-called 'ordinary' teachers are better qualified to implement inclusion than specialists. Here he describes the way he reflected upon his own teacher training and practice before introducing democratic methods into his classroom.

When I graduated from college, I found that the theories I had learnt did not work. I thought that I wasn't being a good teacher. I wasn't doing well and the children weren't doing well. Traditional teaching methods are old-fashioned, so I tried out different methods.

The challenges were that children have different needs and speeds - it was difficult teaching mixed gender and mixed ability classes. There was a big gap between the achievement of girls and boys - girls found it difficult to share 
their ideas with boys. The government opened a unit for children with special needs at our school and this highlighted the needs of the slow learners who were already in our classes.

African tradition does not allow children to come to the fore. Children are told not to speak without adult permission. But they need to be aware of their rights and to speak freely. There is literature in Zambia about rights from UNICEF and child-to-child, but it has not reached every school. The government is trying to achieve democracy, but the children and the community don't understand what it's about. I came to the conclusion that the classroom needed to be democratised so that everyone could learn together.

At first when I encouraged the children to express their views, they spoke too much. It was difficult to grasp what they were saying, but eventually I understood. The children wanted more recreation and play - this was missing from the academic curriculum. They wanted the timetable to be displayed on the wall so that they could check that the teacher was doing what he or she should be doing. They had many other excellent ideas. I was amazed.

At the end of each day, the children looked at the things they had learnt. They were encouraged to point out the positive aspects of each other's behaviour. Some of the so-called 'slow learners' excelled in the practical skill of making toys for the children with disabilities.

The children had to evaluate how I had taught them during the day and how they felt about the teaching. I was then able to feed back to the children how I was going to meet their individual needs.

The Zambian curriculum is very broad, but there are no suggestions about how to teach children about their own situation. I encouraged parents to come to school to participate in the curriculum. I asked them what they wanted their children to learn. I prioritised their wishes and fitted them into the curriculum. Community members were able to volunteer their skills in making teaching aids.

At the end of the term the children wrote down what they had enjoyed most and what they wanted to learn in the following term. They particularly enjoyed carrying out a survey in the community to identify children who were excluded from school either because they had special needs or because they had felt excluded. The children made suggestions and put forward solutions to problems.

The other teachers said that I had no discipline because the children spoke their minds. They feared indiscipline. But actually the children became more conscientious about their own learning. They came to school on time and helped their friends by sharing notes and ideas. At the end of the period the girls had done very well - much better than the boys. There was a 70 per cent pass rate. One girl came third in the whole country. I was no longer at the forefront. My role had changed into a facilitator. I helped the children to organise their ideas. Teaching and learning became more interesting - more like higher education.

The lessons learnt in Mpika and in the programmes supported by Save the Children are highlighted in the following checklist:

- A comprehensive situation analysis should be carried out prior to implementation. 
- Local resources and initiatives should be identified and built on.

- Success does not depend upon a large budget or small class sizes, but on the careful and planned use of existing resources.

- A pilot school should be chosen which will provide a replicable model.

- Training should be ongoing, provided in short courses and preferably take place in schools.

- School improvement is necessary, not optional.

- Programmes should aim to benefit all children, not only disabled children.

- Specialist support should be located at district and national levels, not within schools.

- A whole school approach is essential and good leadership is required.

- The pace of development should be slow to enable those involved to feel comfortable with the changes.

- Ownership should be shared between schools, families and communities.

This example of using child-to-child methods is illustrated on DVD1. It demonstrates that whatever the social and economic situation, pupils can be mobilised to support each other and to support disabled peers, and that in the process all develop and grow intellectually. 